\title{
The sperm nucleus: chromatin, RNA, and the nuclear matrix
}

\author{
Graham D Johnson ${ }^{1}$, Claudia Lalancette ${ }^{1,2}$, Amelia K Linnemann ${ }^{1}$, Frédéric Leduc ${ }^{4}$, \\ Guylain Boissonneault ${ }^{4}$ and Stephen A Krawetz ${ }^{1,2,3}$
}

${ }^{1}$ The Center for Molecular Medicine and Genetics, ${ }^{2}$ Department of Obstetrics and Gynecology and ${ }^{3}$ Institute for Scientific Computing, C.S. Mott Center, Wayne State University of Medicine, 275 East Hancock, Detroit, Michigan 48201, USA and ${ }^{4}$ Department of Biochemistry, Faculty of Medicine, Université de Sherbrooke, Sherbrooke, Québec, Canada $\mathrm{J} 1 \mathrm{H} 5 \mathrm{~N} 4$

Correspondence should be addressed to S A Krawetz; Email: steve@compbio.med.wayne.edu

\begin{abstract}
Within the sperm nucleus, the paternal genome remains functionally inert and protected following protamination. This is marked by a structural morphogenesis that is heralded by a striking reduction in nuclear volume. Despite these changes, both human and mouse spermatozoa maintain low levels of nucleosomes that appear non-randomly distributed throughout the genome. These regions may be necessary for organizing higher order genomic structure through interactions with the nuclear matrix. The promoters of this transcriptionally quiescent genome are differentially marked by modified histones that may poise downstream epigenetic effects. This notion is supported by increasing evidence that the embryo inherits these differing levels of chromatin organization. In concert with the suite of RNAs retained in the mature sperm, they may synergistically interact to direct early embryonic gene expression. Irrespective, these features reflect the transcriptional history of spermatogenic differentiation. As such, they may soon be utilized as clinical markers of male fertility. In this review, we explore and discuss how this may be orchestrated.

Reproduction (2011) 141 21-36
\end{abstract}

\section{Introduction}

Unlike the vast size of the oocyte, the diminutive sperm may have initially seemed unlikely to carry information in excess of its genomic cargo. Indeed, our ability to appreciate the contrary only began to gradually develop over the last two decades. This has been due to several factors, primarily reflecting the distinct nuclear environment of the mature spermatozoon. The sperm genome is repackaged into a near crystalline state, which has proven resistant to dissection often likened to a 'tough nut to crack'. This extensive remodeling both protects the paternal genome and is requisite for the characteristic reduction in nuclear volume which occurs as the head takes on a unique shape (reviewed in Braun (2001) and Balhorn (2007)). The assumption that sperm occupy a limited developmental role compared to oocytes has in part been due to these physical constraints and the appropriate enabling physical, chemical, and biological technologies (Kierszenbaum \& Tres 1975).

Despite the near complete packaging of the sperm genome as protamine (PRM)-associated DNA, it is increasingly clear that specific regions retain a somaticlike structure (reviewed in Miller et al. (2010)). In some cases, these regions are differentially marked by modified histones in a manner reminiscent of the epigenetic states observed in somatic or stem cells (Hammoud et al. 2009, Brykczynska et al. 2010). This feature of sperm chromatin has been suggested to influence the order that genes are repackaged into a nucleosomal bound state and/or expressed following fertilization (reviewed in Rousseaux et al. (2008)). Additionally, sites of histone retention are likely to provide insight into the transcriptional history of spermatogenesis.

RNAs produced during this prior window of transcription are retained in sperm and delivered to the oocyte. The biological role of these transcripts post-fertilization remains a subject of debate. Regardless of their function, several of these molecules are currently being developed as biomarkers of male fertility (Depa-Martynow et al. 2007, Jedrzejczak et al. 2007, Lalancette et al. 2009). Importantly, the notion of a sperm enriched in RNAs continues to expand with the isolation and characterization of a complement of male gamete small noncoding RNAs (sncRNAs; C Lalancette, AE Platts, MP Diamond \& SA Krawetz 2010, unpublished observations).

A subset of sperm RNAs may also serve to structurally support the nuclear matrix. This proteinaceous network present in most cells functionally organizes the genome by binding discreet regions of DNA at sequences termed scaffold/matrix attachment regions (S/MARs). S/MAR binding partitions the genome into cell type-specific 
loop domains, which range in size from 30 to $110 \mathrm{~kb}$ in somatic cells (Vogelstein et al. 1980, Linnemann et al. 2009, Drennan et al. 2010) and from 20 to $50 \mathrm{~kb}$ in sperm (Ward et al. 1989, Barone et al. 1994, Nadel et al. 1995). Nucleosome-bound DNA maintained in mature sperm has been proposed to mark sites of nuclear matrix attachment in these cells. These structural markers likely correspond to the S/MARs anchoring the decondensed DNA loops of prior cell types and may serve to recapitulate paternal nuclear architecture in the zygote (Ward 2010).

The notion that the male gamete merely delivers paternal DNA to the oocyte is falling by the wayside. This reflects several developments pertaining to the interacting function of the three main structural genetic elements of the sperm nucleus: chromatin, RNA, and the nuclear matrix. In a manner accessible to all reproductive biologists, this review explores and discusses how this unique nuclear symphony may be conducted. As such, when appropriate, a role for paternal chromatin, RNA, and the nuclear matrix beyond the interior of the sperm nucleus is discussed in terms of potential impact on embryonic development. While not the primary focus of this review, one is also referred to several timely reviews discussing paternal imprinting, the transgenerational effects of germline mutations (Butler 2009, Nadeau 2009, de Boer et al. 2010) providing additional perspectives.

\section{Sperm chromatin}

Spermatogenesis is characterized by ordered histone replacement. As spermatogonia commit to this differentiative pathway, they have already begun to incorporate testis-specific histone variants into their chromatin (Meistrich et al. 1985, van Roijen et al. 1998). Synthesis and deposition of these proteins peak during meiosis (Kimmins \& Sassone-Corsi 2005). Supported by the action of testis-specific histone variants, in round spermatids, the majority of histones are replaced first by the transition proteins (TNPs) and subsequently by PRMs. Some histone variants, as well as canonical histones, are maintained throughout the remaining stages of spermatogenesis (Shires et al. 1976, Seyedin \& Kistler 1980, Gatewood et al. 1987, 1990, Witt et al. 1996, Chadwick \& Willard 2001, Zalensky et al. 2002, Yan et al. 2003, Churikov et al. 2004a, reviewed in Churikov et al. (2004b), Tanaka et al. (2005) and Govin et al. (2007)).

Chromatin remodeling requires regulated post-translational modifications of histones including acetylation (Oliva \& Mezquita 1982, Christensen et al. 1984, Grimes \& Henderson 1984, Meistrich et al. 1992, Marcon \& Boissonneault 2004), ubiquitination (Chen et al. 1998, Baarends et al. 1999, Lu et al. 2010), methylation (Godmann et al. 2007), and phosphorylation (MeyerFicca et al. 2005, Krishnamoorthy et al. 2006, Leduc et al. 2008a), and has been recently reviewed in the context of spermatogenesis (Rousseaux \& Ferro 2009). Among these modifications, the best characterized to date is the global hyperacetylation of histones. Incorporation of these marks destabilizes nucleosomes in preparation for their replacement by the TNPs and ultimately by the PRMs (Pivot-Pajot et al. 2003, Kurtz et al. 2007).

Hyperacetylation is essential in mice and men as perturbation is correlated with defective spermatogenesis (Sonnack et al. 2002, Fenic et al. 2004). This is supported by the observation that species maintaining chromatin in a somatic-like state do not exhibit elevated levels of histone acetylation in sperm (Christensen et al. 1984). For example, trout spermiogenesis spans several weeks during which spermatids exhibit high steady state levels of hyperacetylation. Extended maintenance of this modification in the absence of protamination suggests that additional factors are needed to complete nuclear remodeling (Christensen et al. 1984, Csordas 1990). Even precocious hyperacetylation in Drosophila does not prematurely induce the histone to PRM spermatid transition (Awe \& Renkawitz-Pohl 2010). There are several potential pathways regulating initiation of chromatin remodeling. However, inhibition of the ubiquitin-proteasome pathway by loss of an ubiquitin ligase can block global histone acetylation, degradation, and PRM deposition, resulting in sterility (Lawrence 1994, Roest et al. 1996, Lu et al. 2010). In these studies, mature spermatozoa were low in number and exhibited altered morphologies, reminiscent of teratozoospermia. Indeed, microarray analysis of sperm RNAs from teratozoospermic patients presents a severe disruption of the ubiquitination pathway (Platts et al. 2007).

During murine and human protamination, histones are replaced first by the TNPs then subsequently displaced by the PRMs (Balhorn et al. 1984). Binding of these small arginine-rich proteins to the negatively charged phosphodiester backbone of the double helix abolishes the electrostatic repulsion between the proximal chromatin strands resulting in the formation of a toroid loop (Hud et al. 1993). Containing $\sim 50 \mathrm{~kb}$ of DNA, these donut-shaped structures are further stabilized by inter- and intramolecular disulfide bridges compressing the genome into a semi-crystalline state as the spermatozoon transits through the epididymis (Golan et al. 1996). The resulting mature human sperm nucleus is now condensed to $1 / 13$ th the size of that of the oocyte (Martins \& Krawetz 2007b).

Despite compaction, the restructured paternal chromatin retains a hierarchical layer of genomic organization (Zalensky \& Zalenskaya 2007). Reminiscent of somatic cells, individual chromosomes are not randomly positioned, but occupy rather distinct territories preferentially localized within the nucleus with respect to one another (Hazzouri et al. 2000, Zalenskaya \& Zalensky 2004). The positioning of chromosome territories in porcine spermatozoa is first observed in spermatids. Preceding meiosis, their relative position resembles that seen in somatic cells (Foster et al. 2005). It has 
been proposed that within sperm, each chromosome territory generally adopts a 'looped hairpin' conformation orienting its centromere towards the nuclear interior and distal telomeres towards the periphery (Mudrak et al. 2005).

Nuclear remodeling has been proposed to serve three functions (Braun 2001). First, the reduced size and shape of the sperm nucleus yields a hydrodynamic structure that is predictive of fertility in bulls and red deer (Ostermeier et al. 2001, Malo et al. 2006, Gomendio et al. 2007). Second, protamination renders the majority of the sperm genome resistant to nuclease attack, irradiation, and shearing forces (Kuretake et al. 1996, Wykes \& Krawetz 2003, Rathke et al. 2010). Presumably, both features were evolutionarily optimized to protect the paternal genome while traversing the female reproductive tract en route to the oocyte. Third, although a subject of debate, the selective post-meiotic retention of histones provides the zygote a dichotomous chromatin package that could serve to preferentially poise regions for early use (Gatewood et al. 1987, Hammoud et al. 2009, Brykczynska et al. 2010).

Murine spermatozoa organize about $1-2 \%$ of their genome with nucleosomes (Balhorn et al. 1977, Brykczynska et al. 2010), whereas up to $15 \%$ of human sperm DNA is packaged in this manner (Tanphaichitr et al. 1978, Gusse et al. 1986, Gatewood et al. 1990). Interrogation of isolated nucleosomeassociated sequences demonstrated that some of these genomic regions included imprinted regions (Banerjee \& Smallwood 1998), telomeres (Pittoggi et al. 1999, Zalenskaya et al. 2000), retroposon DNA (Pittoggi et al. 1999), and specific gene loci (Gardiner-Garden et al. 1998, Pittoggi et al. 1999, Wykes \& Krawetz 2003). Lacking comparable nucleosomal enrichment, the centromeric and pericentromeric regions of mammalian sperm present a mix of nucleosomes and PRMs (Wykes \& Krawetz 2003). Specifically, these regions retain modified histones such as $\mathrm{H} 3 \mathrm{~K} 9 \mathrm{me} 3$ as well as the histone variants CENPA and H2A.Z (Palmer et al. 1990, Zalensky et al. 1993, Hammoud et al. 2009). Together these observations led to the hypothesis that the maintenance of nucleosomes at specific sites may prime discreet regions for use shortly after fertilization. Initial support for this premise came from the finding that, in human sperm, histones bind DNA in a sequencespecific manner around gene regulatory regions (Gatewood et al. 1987, Wykes \& Krawetz 2003).

Studies reporting the in situ localization of nucleosome-associated genomic regions in the sperm should be met with caution. The compact nuclear environment of the spermatozoa cannot be accurately interrogated by immunofluorescence without prior membrane destabilization and chromatin decondensation. Treatment may skew interpretations as decondensation alters the position of nuclear elements (van Roijen et al. 1998). With this caveat, in human spermatozoa, core histones as well as testes-specific histone variants have been observed within the basal portion of the nucleus proximal to the tail (Zalensky et al. 2002, Li et al. 2008). In contrast, histone $\mathrm{H} 2 \mathrm{~B}$ as well as nucleosome-associated telomeric regions exhibits a partially overlapping punctuate pattern throughout the nucleus (Gineitis et al. 2000, Zalensky et al. 2002). In the mouse, telomeres are bound by linker $\mathrm{H} 1$, which is absent in human sperm, and appear localized to the periphery (Gatewood et al. 1990, Pittoggi et al. 1999). It cannot be excluded that these results primarily reflect nuclear access. As an additional point of comparison, the canonical histones found in spermatozoa of the evolutionarily distant marsupial, Sminthopsis crassicaudata, are also peripherally located (Soon et al. 1997). Regardless of the limitations inherent to these studies, it is generally agreed that the nucleoprotamine and nucleohistone components in sperm are discreetly partitioned (van der Heijden et al. 2006, Li et al. 2008).

Recent advances in methods of genome-wide analysis now allow for the detection of histone-enriched regions at the primary sequence level. Using CGH tiling arrays, it was established that histone-bound DNA is associated with gene-dense regions and enriched for developmentally regulated promoters as well as CTCF binding sites (Arpanahi et al. 2009). In parallel, next generation sequencing (NGS) provided a significantly higher resolution analysis (Hammoud et al. 2009). Nucleosome-associated sequences exhibited a modest enrichment within the promoters of developmentally important genes including embryonic transcription factors and signaling pathway components, as well as microRNA (miRNA) and imprinted gene clusters. Independent analysis has demonstrated that internal exons also display significantly greater histone enrichment than flanking intronic sequences (Nahkuri et al. 2009). Outside of promoters, histones were found to be distributed, at low levels, throughout the genome. This pattern of nucleosome retention has recently been confirmed using similar NGS technologies (Brykczynska et al. 2010).

Combining chromatin immunoprecipitation (ChIP) and NGS (i.e. ChIP-seq) revealed that developmentally regulated promoters may be bivalently marked by H3K4me2/3 and H3K27me3 (Hammoud et al. 2009, Brykczynska et al. 2010). The bivalent promoter is a hallmark of developmentally regulated stem cell genes and has recently been observed in zebrafish blastomeres (Vastenhouw et al. 2010). In addition to harboring sites of both active and repressive histone modifications, bivalent promoters are often bound by RNA polymerase and are therefore poised for expression. To date, this correlation has not been established in mature sperm. The coordinated removal of repressive H3K27me3 throughout differentiation permits the initiation of transcription, providing temporal and spatial 
control of gene expression. Bivalent promoters might reflect the male contribution to early gene expression (Petronis 2010).

Alternatively, differential enrichment of histone modifications within specific ontological categories of promoters, and not bivalency, may regulate early embryonic gene expression (Brykczynska et al. 2010). In human sperm, H3K4me2 marked promoters of genes associated with spermatogenic and housekeeping processes, whereas $\mathrm{H} 3 \mathrm{~K} 27 \mathrm{me} 3$ was enriched within the promoters of developmentally regulated genes expressed following implantation or in differentiated cells. Furthermore, the degree to which a promoter was occupied by H3K27me3 positively correlated with repression of the corresponding gene during early mouse embryonic development. Together these results argue that the retention of the repressive H3K27me3 modification at specific promoters in human sperm may provide a paternal and possibly transgenerational mark (Petronis 2010).

The two modes of paternally derived epigenetic promoter regulation introduced above, bivalency and differential enrichment of modified histones, are likely present in sperm of both mice and men. As illustrated in Fig. 1, the use of one mechanism in lieu of the other would be expected to hinge on shared spermatogenic transcriptional requirements and the speciesspecific timing of zygotic genome activation (ZGA).

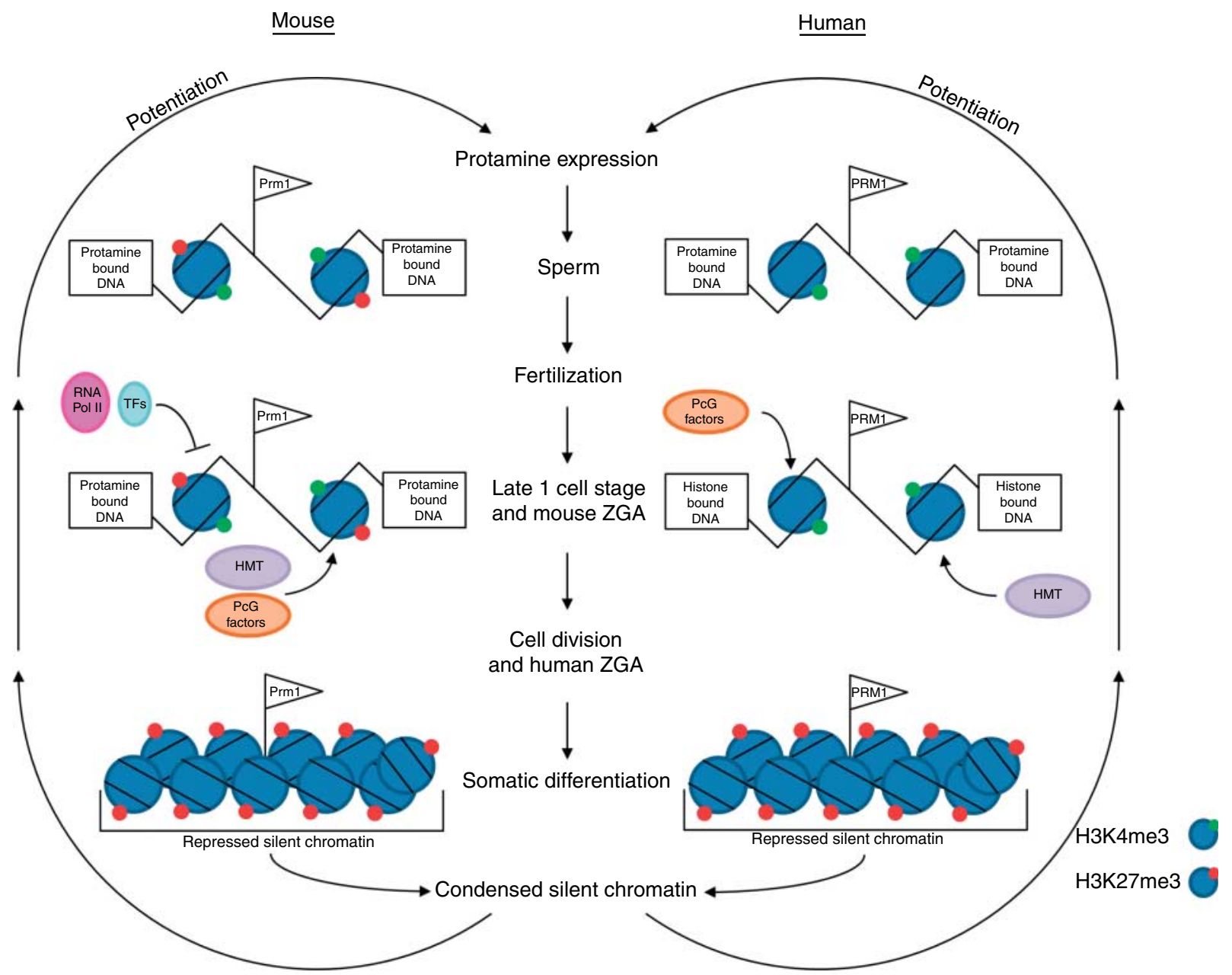

Figure 1 The potential influence of zygotic genome activation on paternal chromatin structure. In mouse and human sperm, the protamine genes are bound by nucleosomes residing within a potentiated DNase I-sensitive domain. These regions are differentially marked by modified histones in each species. In mouse, the bivalently marked spermatogenic promoters may reflect the early initiation of zygotic expression at the late one-cell stage. Recruitment of transcriptional machinery (RNA polymerase, RNA Pol II; transcription factors, TFs) is coincident with the activation of silencing pathways (histone methyltransferases, HMTs; polycomb factors, $\mathrm{PCG}$ ). The retention of the silencing $\mathrm{H} 3 \mathrm{~K} 27$ me 3 mark in promoters may prevent detrimental expression prior to gene silencing. In comparison, human zygotic genome activation occurs at the four- or eight-cell stage. This affords the embryo time to silence these genes, which in sperm are marked with the active H3K4me3 modification lacking the repressive mark. In both species, the protamine domain remains silenced throughout differentiation by adopting a highly condensed chromatin conformation. During male gametogenesis, this region becomes potentiated in spermatocytes prior to its expression in round spermatids. 
Whereas promoters of potent developmental regulators in sperm from both species are primarily associated with repressive histone modifications, spermatogenic genes are bivalently marked in murine but not in human sperm (Brykczynska et al. 2010). The former reflects a shared need for early repression of developmental gene expression. The presence of active modifications in mouse and human spermatogenic promoters likely corresponds to the transcriptional history of these silent cells. In mouse, these regions are marked by repressive histone modifications to ensure their appropriate regulation following fertilization. Mice initiate ZGA late in the one-cell embryo (Schultz 2002, Minami et al. 2007), concurrent with DNA replication (Aoki et al. 1997). This is paralleled by an increase in the levels of $\mathrm{H} 3 \mathrm{~K} 27 \mathrm{me} 3$ within the paternal pronuclei through the activity of polycomb group (PcG) proteins (Santos et al. 2005). Prior to this, H3K27me3 cannot be microscopically detected in paternal chromatin of the one-cell fertilized oocyte (Santos et al. 2005, van der Heijden et al. 2005, Puschendorf et al. 2008). Methylated sperm histones are expected to remain reflecting the lack of histone demethylase activity in either the oocyte or the zygote (Puschendorf et al. 2008). This is likely essential to ensure proper transcriptional regulation from the paternal chromatin during this initial wave of ZGA. Concomitantly, the male pronucleus exhibits a higher level of transcriptional activity (Aoki et al. 1997), an increased concentration of transcription factors (Worrad et al. 1994), and a more transcriptionally permissive chromatin structure compared to the female pronucleus (Adenot et al. 1997, Schultz 2002). It is reasonable to assume that the presence of sperm-derived $\mathrm{H} 3 \mathrm{~K} 27 \mathrm{me} 3$ within the bivalent promoters of the paternal spermatogenic genes enables the propagation of the polycomb repressive mark preventing their transcription (Margueron et al. 2009, Brykczynska et al. 2010). This would be expected to block transcription factor recruitment and subsequent expression. Repression of these genes is necessary as expression of PRM1, which is bivalently marked in mouse sperm, would likely perturb further development (Lee et al. 1995). Indeed, mutant mice lacking the methyltransferase activity (required to propagate $\mathrm{H} 3 \mathrm{~K} 27 \mathrm{me} 3$ ) do not progress past early development $\left(\mathrm{O}^{\prime}\right.$ Carroll et al. 2001). Though undoubtedly this mutation is responsible for a wide range of developmental defects (Erhardt et al. 2003, Puschendorf et al. 2008), it would be informative to probe these late zygotic mutants for expression of those spermatogenic genes marked by a bivalent promoter in wild-type sperm. Comparatively, the delayed ZGA of humans (Braude et al. 1988) should permit PcG-mediated repression of orthologous spermatogenic promoters altering the paternally derived poised chromatin structure. The inability to detect trimethylated paternal $\mathrm{H} 3 \mathrm{~K} 27$ in G2 tripronuclear zygotes suggests that deposition of this modification occurs sometime after the first cleavage event but before the start of embryonic gene expression at the four- to eight-cell stage (van der Heijden et al. 2009).

The number of histone variants and associated secondary modifications found in mammalian sperm has greatly increased in the last two decades (reviewed in Rousseaux \& Ferro (2009) and Carrell \& Hammoud (2010)). Detection of these proteins following fertilization has proven challenging for several reasons. First, the amount of histone-associated chromatin in sperm is limited, ranging from 1 to $15 \%$ in mice and men respectively. Secondly, epitopes may be inaccessible prior to decondensation limiting detection. Thirdly, deposition of maternal histones, which are virtually indistinguishable from their paternally derived counterparts, directly coincides with sperm chromatin decondensation (van der Heijden et al. 2005, 2008). This is best exemplified by the replication-independent histone variant H3.3. Though, present in mature sperm (Gatewood et al. 1990), H3.3 is not microscopically detectable in paternal chromatin until maternally derived histones are deposited at the start of decondensation (van der Heijden et al. 2005, Torres-Padilla et al. 2006), the prevalence of this variant in paternal chromatin is conserved and likely essential to remodeling as mutation of the HIRA chaperone blocks H3.3 incorporation precluding decondensation in Drosophila zygotes (Loppin et al. 2005, Ooi \& Henikoff 2007).

Despite the difficulty in detecting nucleosome-bound DNA delivered by sperm, some paternally derived modified histones and histone variants have been observed following fertilization. These include both H4K8ac and H4K12ac (van der Heijden et al. 2006) as well as the testis-specific variants H2AL1 and H2AL2. First detected in the centromeres of spermatids, these variants remain enriched in heterochromatin until displaced from paternal DNA shortly after fertilization (Wu et al. 2008). In contrast to histone, H3 replicationdependent variants H3.1 and H3.2 (Tagami et al. 2004) are detected following fertilization in decondensed sperm chromatin prior to DNA synthesis, though in much lower abundance than in maternal chromatin (van der Heijden et al. 2005, 2008). These sperm-derived proteins are detected until the zygotic $S$ phase initiates, at which point they become indistinguishable from their newly incorporated maternal counterparts (van der Heijden et al. 2008).

As described above, many sites of histone enrichment likely have no impact on the zygote and simply reflect the transcriptional history of these silent cells. Indeed, this has been hypothesized to be the role of H3K4me2 in human sperm (Brykczynska et al. 2010). A comparison of the genic regions, which remain associated with nucleosomes following spermiogenesis to those RNAs retained in sperm, may help identify this population of promoters. 


\section{RNA in sperm}

It is now accepted that mature spermatozoa harbor a distinct population of RNAs. The biological role of these transcripts largely remains unknown. Undoubtedly, some of the transcripts retained in sperm represent products expressed in various spermatogenic cells. The proposed functions of others include the regulation of early embryonic gene expression and stabilization of the nuclear matrix.

Owing to the observation that mature mammalian sperm are transcriptionally quiescent (Kierszenbaum \& Tres 1975), the presence of mRNAs in these cells was originally thought to represent incomplete expulsion of cytoplasmic elements during nuclear condensation. Indeed, sperm do contain remnants of their developmental expression profile, which seemingly serve no purpose in the mature gamete. Furthermore, some of these RNAs are highly abundant in sperm and expected to be detrimental to the embryo (Lee et al. 1995). In this regard, the PRM transcripts are the most conspicuous. Following their transcription in round spermatids, these RNAs are translationally repressed and stored as inactive messenger ribonucleoprotein particles prior to remodeling (Kleene 1989, Kwon \& Hecht 1993). Loss of this repression causes premature PRM translation in these cells. The subsequent developmental arrest is likely due to precocious PRM-dependent nuclear condensation. Nuclei from these cells, such as those from mature spermatozoa, are sonication resistant (Lee et al. 1995, Kuretake et al. 1996). The affinity of PRMs for DNA coupled with the enduring abundance of these transcriptionally repressed RNAs in sperm presents a potentially precarious situation to the zygote. However, failure to detect these transcripts soon after fertilization by ICSI or round spermatid injection despite the persistence of other sperm RNAs (Ziyyat \& Lefevre 2001, Avendano et al. 2009) suggests that the zygote has evolved mechanisms and pathways to cope with this consequence of paternal genome compaction.

An evolutionarily distant precedent for such a mechanism has recently been observed in Arabidopsis (Bayer et al. 2009). Expressed during male gametogenesis, short suspensor (SSP) transcripts are translationally repressed and stored in pollen. Following fertilization, repression is relieved, and the SSP gene product undergoes zygotic translation. Sufficient accumulation of this protein in the seed activates a MAP kinase signaling cascade prompting the first cell division. In this model, embryo patterning is temporally linked to fertilization by a paternally contributed mRNA. Whether such regulation exists in other species is the subject of intense debate. It should be noted that parthenogenetic mice survive to adulthood and produce offspring in the absence of a paternal factor (Kono et al. 2004, Kawahara et al. 2007). However, efficient generation of these embryos requires the deletions of both copies of two paternally methylated imprinting control regions.
Furthermore, the possibility that transgenerational affects may present must be considered.

Regardless of species, if paternally derived mRNAs are to impact embryogenesis, they must, like SSP, first be selectively stored in sperm. Aiding in the detection of transcripts that fulfill this prerequisite has been the development of high throughput technologies. Accordingly, the use of microarrays to screen RNA profiles from human sperm and preceding cell types provided the first evidence for the existence of a sperm-specific transcript (Ostermeier et al. 2002). Interestingly, in the bull, despite a high percentage $(\sim 37 \%)$ of transcripts being shared between cell types, the majority of mRNAs $(59 \%)$ present in round spermatids are absent in the mature gamete (Gilbert et al. 2007). In addition to the selective loss of transcripts, $\sim 120$ RNAs were enriched in sperm compared to spermatids.

Comparing transcripts retained in sperm from pooled and individual human ejaculates suggested the existence of a common spermatozoal mRNA fingerprint (Ostermeier et al. 2002). Intriguingly, the RNA profile shared among these fertile donors included transcripts implicated in fertilization and development (Ostermeier et al. 2002). Some of these mRNAs are absent in human and hamster oocytes but are present in embryos (Kocabas et al. 2006, Avendano et al. 2009). Several laboratories have since independently observed these RNAs in zygotes following heterologous fertilization (Ostermeier et al. 2004, Avendano et al. 2009). These findings suggest that in a species-specific manner, some mRNAs are selectively retained in mature spermatozoa, delivered to the oocyte, and persist in the zygote.

Early investigations comparing sperm RNAs from pooled and individual fertile donors identified few, if any, differences between samples (Ostermeier et al. 2002). However, recent technological advances have resolved their variability (Lalancette et al. 2009). This may be due to the inherent heterogeneity of sperm (Lefievre et al. 2007, Lewis 2007), as evidenced by the normalization of transcript profiles following sperm selection (Garcia-Herrero et al. 2010). For example, when sperm mRNA profiles from 24 fertile individuals (Lalancette et al. 2009) were clustered using standard microarray comparative techniques, groups of samples clustered to differing degrees. However, a total of 453 transcripts were detected above background in all 24 samples. Of these, 30 'transcript pairs' were identified on the basis that although the signal intensity of the transcripts changed from one sample to another, this change occurs in parallel, such that the signal ratio of two transcripts in a pair was relatively stable across all 24 samples. This method of microarray analysis has since been utilized to evaluate tumor gene networks for diagnosis and prognosis, which also exhibit considerable variability between individual transcript profiles (Platts et al. 2010). Interestingly, transcripts known to be translationally repressed in mature spermatozoa were 
detected, though none formed 'stable pairs'. Whether the paired transcripts are also translationally repressed and by what mechanism(s) remains to be elucidated. Irrespectively, the non-random enrichment of RNAs in sperm suggests that these RNAs are not solely remnants of transcription. Though some paternal transcripts may function in the early embryo, it seems unlikely that all of the selectively retained mRNAs stored by the male gamete should impact development. What other functions can be ascribed to these transcripts?

With the exception of PLC zeta (Parrington et al. 1999), it is not known whether the proteins corresponding to the majority of these retained transcripts are also present in mature spermatozoa and what proteins survive delivery to the oocyte. Comparing these mRNAs to the still developing sperm proteome (Baker et al. 2008, Oliva et al. 2008, Baker \& Aitken 2009, Nixon et al. 2009) would help guide future investigations concerning the functional significance of the spermretained transcripts. This approach was recently used to demonstrate the selective retention of mRNAs expressed from the non-recombining region of the human $\mathrm{Y}$ chromosome (Yao et al. 2010).

Analysis of the sperm transcripts cannot be confined solely to mRNA. Acceptance of RNA in sperm was well timed with the discovery of RNAi (RNA interference) and the subsequent appreciation for the biological role of sncRNAs and their initial identification in spermatozoa (Moldenhauer et al. 2003). sncRNAs are approximately between 18 and 30 nucleotides in size, and classified in families according to their biogenesis (Moazed 2009). In somatic cells, these transcripts contribute to gene regulation and chromatin structure, and inhibit transposition. Two of the most studied classes of sncRNAs are the small interfering RNA (siRNA) and the miRNA families. These molecules of 20-24 nucleotides are processed from hairpins through pathways involving DICER, an endoribonuclease of the RNase III family. Data pertaining to these male germline transcripts in testis have recently been reviewed (Papaioannou \& Nef 2010). However, they remain largely uncharacterized in mature sperm (C Lalancette, AE Platts, MP Diamond \& SA Krawetz 2010, unpublished observations).

In addition to siRNAs and miRNAs, the testis expresses piwi-interacting RNAs (piRNAs). These transcripts of 2630 nucleotides are produced in a DICER-independent manner that does not require double-stranded RNA folding (reviewed in Klattenhoff \& Theurkauf (2008) and Ghildiyal \& Zamore (2009)). Complementary to transposons, these RNAs repress the rate of transposition, thereby protecting the genome from mobile elements. Currently, the presence of these small RNAs has been demonstrated in spermatogenic cells (reviewed in Lau (2010)) where their function is essential to spermatogenesis (Deng \& Lin 2002, Kuramochi-Miyagawa et al. 2004). Though assumed to be absent from the mature gamete, a restricted set of piRNAs may be retained in human spermatozoa (C Lalancette, AE Platts, MP Diamond \& SA Krawetz 2010, unpublished observations).

The demonstration that miRNAs, and other small RNAs, are retained in the mammalian sperm nucleus and similar to mRNAs delivered to the zygote has ignited much debate (Ostermeier et al. 2005, Amanai et al. 2006, Yan et al. 2008, Curry et al. 2009). The absence of transcriptional activity in sperm has prompted the hypothesis that paternally contributed miRNAs may regulate early embryonic expression influencing offspring phenotype (Rassoulzadegan et al. 2006, Grandjean et al. 2009). However, the current pace at which novel sncRNAs can be identified by high throughput sequencing technologies far surpasses the ability to determine their biological role, if any. A detailed catalog and analysis of the sperm RNA are wanting.

Towards this end, a recent study has provided the first glimpse of the complexity of this component of the sperm transcriptome (C Lalancette, AE Platts, MP Diamond \& SA Krawetz 2010, unpublished observations). Small sperm RNAs $(<200 \mathrm{bp})$ purified from single ejaculates from three fertile donors were subjected to high throughput sequencing. Isolated sncRNAs comprised $\sim 3$ of the 10-20 fg of the RNA found in an individual sperm (Krawetz 2005). The average length of these transcripts was $18 \mathrm{bp}$. Sequenced reads were classified as either aligning uniquely or to multiple locations (two to ten sites) throughout the genome. Greater than half of the RNAs (58\%) mapped to multiple locations in the genome. The majority $(70 \%)$ of uniquely mapped reads correspond to novel sncRNAs primarily derived from intronic and intergenic regions. The miRNAs were a small percentage $(3 \%)$ of the known sncRNAs in those that uniquely aligned to the genome as well as those that aligned to multiple locations.

Though miRNAs were the first class of sncRNAs observed in mammalian sperm, they account for relatively few of the sncRNAs shared between donors. However, there may only be limited opportunities for post-transcriptional regulation of early development by miRNAs. Indeed, recent reports have established that this pathway is strongly down-regulated during oocyte maturation and not required for preimplantation development (Ma et al. 2010, Suh et al. 2010). Perhaps, paternal miRNAs and other short RNA species delivered to the zygote bypass their canonical regulatory pathway altogether. In somatic cells, sncRNAs and short RNAs ( 50-200 nt) bind to complimentary promoter regions silencing gene transcription through the recruitment of PcG proteins and repressive histone marks (Kim et al. 2008, Kanhere et al. 2010). The majority of miRNAs identified in sperm (C Lalancette, AE Platts, MP Diamond \& SA Krawetz 2010, unpublished observations) originate from promoter regions. These transcripts may bind to paternal DNA during nuclear remodeling such that they are delivered to the oocyte in association with their targeted cis sequences presumably influencing their local chromatin structure. 


\section{The sperm nuclear matrix}

As discussed above, appreciation that the mature spermatozoon is more than a vehicle for the delivery of inert DNA has evolved with the acceptance that distinct regions of the paternal genome remain nucleosomebound (Gardiner-Garden et al. 1998, Wykes \& Krawetz 2003, Arpanahi et al. 2009, Hammoud et al. 2009). Complementing this development was the discovery that sperm also deliver a suite of RNAs to the oocyte (Ostermeier et al. 2004). Both have contributed to expanding the post-fertilization genetic influence of the male gamete. Our understanding of how these elements coalesce to potentially influence embryonic development would not be complete without considering the RNA containing nuclear matrix (Malyavantham et al. 2008).

In most cells, DNA is functionally organized by a proteinaceous network termed the nuclear matrix (Cook \& Brazell 1975, Ward et al. 1989, Choudhary et al. 1995, Kramer \& Krawetz 1996, Heng et al. 2004, Linnemann \& Krawetz 2009a, 2009b, Ward 2010). When isolated and viewed by electron microscopy, this ultrastructure resembles the fibrous architecture of the cytoskeleton (Comings \& Okada 1976, Berezney \& Coffey 1977, Fey et al. 1984). The list of proteins comprising the nuclear matrix is vast and to some degree cell type-dependent (reviewed in Mika \& Rost (2005) and Albrethsen et al. (2009)). Associated with the sperm nuclear matrix are various structural proteins such as actin, myosin, and lamin B, as well as transcription factors and chromatin modifiers such as the topoisomerases (Moss et al. 1993, Carrey et al. 2002, Ocampo et al. 2005, Har-Vardi et al. 2007). Only recently, spermatozoa have, similar to somatic cells, been shown to contain a population of RNAs that associate with the nuclear matrix (reviewed in Lalancette et al. (2008)). Perhaps these transcripts fulfill a structural role.

The ordered positioning of chromatin within the nucleus results from attachment of discrete S/MAR sequences to this network of proteins and RNAs. Chromatin anchored to the matrix by S/MARs forms cell type-specific loop domains within interphase nuclei. Differential matrix attachment has been shown to coincide with DNA synthesis (Adom \& Richard-Foy 1991, Anachkova et al. 2005, Courbet et al. 2008) and contribute to cell type-specific gene expression (Heng et al. 2004, Linnemann \& Krawetz 2009a, 2009b). Despite the absence of replication and transcription in sperm, evidence suggests that the nuclear matrix both structurally orders and imparts function to the paternal genome.

Studies investigating the role of the sperm nuclear matrix commonly require chromatin to be relieved of PRM compaction. Treating sperm with alkali or high concentrations of buffered salts in the presence of a reducing agent such as dithiothreitol (DTT) displaces PRMs and the remaining histones. However, the strong interactions between DNA and nuclear matrix appear preserved (Ward et al. 1989). Once decondensed, the otherwise unconstrained DNA loops radiate out from the matrix forming a diffuse weakly staining halo around a brightly staining central region. The strong fluorescent signal corresponds to chromatin at the bases of the DNA loop domains which remain associated with the nuclear matrix (Kramer \& Krawetz 1996). Similar extraction protocols are commonly used with somatic cells; though due to the absence of disulfide bonds, reducing agents are not required (Berezney \& Coffey 1977, Linnemann et al. 2009, Drennan et al. 2010).

Studies of sperm nuclear halos have yielded estimates of the length of individual DNA loops (20-50 kb), which approximately correspond to the amount of DNA within an individual toroid (Ward et al. 1989, Hud et al. 1993, Barone et al. 1994, Nadel et al. 1995). This observation has prompted the notion that these discrete subunits of DNA are directly related (Ward 1993). It was proposed that during spermiogenesis, individual DNA loop domains condense to form single toroid structures (Ward 2010). Each toroid is then tethered to the nuclear matrix by adjacent nuclease-sensitive linker regions. These regions are expected to correspond to the S/MARs flanking DNA loop domains. Nuclease sensitivity would be ensured if these sequences escaped protamination. Accordingly, following sperm chromatin decondensation, these linker regions may be used to recapitulate the paternal DNA structure (Ward 2010).

Support for this model comes from the observation that spermatozoa possess endogenous nuclease activity that releases $50 \mathrm{~kb}$ DNA fragments (Sotolongo et al. 2005). Unlike the proposed nuclease-sensitive linker regions, the PRM-bound sequences would be shielded from degradation. Preferential digestion of the chromatin tethers would release the toroids, each of which contains a DNA sequence of approximately uniform length.

In addition to partitioning the sperm genome, the nuclear matrix may serve as a platform for the transgenerational inheritance of paternal chromatin structure. The proposal that matrix-associated linker regions in sperm may be recycled as embryonic S/MARs (Ward 2010) demarcating the initial embryonic replicons is broadly evidenced by the chromatin architecture of embryonic stem cells (ES cells). Unconstrained DNA loops in mammalian sperm and ES cells are reduced in size compared to those present in the liver or brain (Klaus et al. 2001, Ward 2010). The large widely spaced chromatin loops of differentiated mammalian cells are also observed in Xenopus erythrocytes. Nuclei from these cells incubated with M-phase egg extract remodel their chromatin structure to resemble the condensed narrowly space DNA loops of sperm and early embryonic cells. Once remodeled, these nuclei replicate their DNA at an efficiency and rate similar to that of the undifferentiated cells (Lemaitre et al. 2005). This activity is dependent on TOP2 as well as acetylated H3/4 (Adenot et al. 1997, Shaman et al. 2006). These results 
suggest that the ordered positioning of chromatin domains by the sperm nuclear matrix persists in the early embryo and directs initial DNA synthesis.

Additional evidence for the inheritance of sperm DNA architecture has been garnered. Experimental disruption of the sperm nuclear matrix by treatment with detergent precludes embryogenesis following ICSI (Ward et al. 1999). Injection of intact sperm nuclear halos into oocytes supports the formation of male pronuclei capable of DNA replication. Similar results are achieved after restricted endonuclease digestion of extracted loop domains prior to ICSI. Maintenance of MAR sequences in conjunction with an intact nuclear matrix was sufficient to support the formation of the male pronucleus and subsequent paternal DNA replication. However, neither occurred when oocytes were injected with isolated DNA, DNase I-digested nuclear matrices, or both in parallel (Shaman et al. 2007). The necessity of the interaction between MARs and the nuclear matrix was confirmed by inducing TOP2-mediated cleavage presumably at toroid linker regions prior to ICSI. Loss of this association resulted in irreversible degradation of paternal DNA by as yet unidentified factors (Shaman et al. 2006). Several reports suggest a role for TOP2 after fertilization during sperm decondensation and pronuclear formation. However, it is not clear whether this activity in the oocyte is due to paternally or maternally derived enzyme (Bizzaro et al. 2000, St Pierre et al. 2002, Tateno \& Kamiguchi 2004). Regardless, inheritance of an intact sperm nuclear matrix, regulated by TOP2, is expected to be essential to the initial stages of development as it likely orders the paternal chromatin structure.

Support for the hypothesis that the sperm nuclear matrix mediates a form of non-genetic information between parent and offspring has also been inferred from the studies of transgenerational genetic instability following germline exposure to toxins or radiation (reviewed in de Boer et al. (2010)). Chronic paternal exposure to low doses of cyclophosphamide (CPA) is correlated with an altered sperm nuclear matrix protein profile as well as abnormal chromatin condensation (Codrington et al. 2007a, 2007b). Pairing treated sires with healthy mares increased preimplantation loss as well as developmental defects. These were correlated with precocious DNA decondensation, an increase in DNA damage, perturbed gene expression, and changes in the timing of ZGA (Harrouk et al. 2000a, 2000b, 2000c, Grenier et al. 2010). These effects cannot be reconciled by the altered composition of the sperm nuclear matrices alone. Chronic exposure of postmeiotic spermiogenic cells to CPA results in varying types of DNA damage (Codrington et al. 2004). The lack of DNA repair in post-meiotic cells propagates these errors. The effects of CPA might be exacerbated by changes to higher order chromatin structure including reordered associations between S/MARs and the nuclear matrix, as these interactions are thought to be essential to early development.

Additional evidence for the sperm nuclear matrix influencing male fertility has been provided (Barone et al. 2000, Ankem et al. 2002). Infertile cryptorchidic patients presented with sperm nuclear matrix instability. Though hampered by a small sample size, this study supports the view that evaluation of sperm nuclear matrix stability could be informative in certain cases of male factor infertility. Similarly, the level of sperm DNA fragmentation may discriminate between damage to chromatin associated with the nuclear matrix, the proposed toroid linker regions, and that of the toroid DNA itself (Ward 2010). The role of DNA damage and its use in predicting male fertility have been reviewed elsewhere (Leduc et al. 2008b, Lewis et al. 2008, Aitken \& Koppers 2011, Barratt et al. 2010).

Demonstrating transgenerational inheritance of paternal chromatin structure requires delineation of those DNA sequences associated with the nuclear matrix in sperm and the paternal pronucleus. Though a direct comparison is limited to model species, investigation of these interactions in human sperm is underway. Instrumental to this effort has been the increased sequence resolution afforded by newer high throughput technologies. These include the development of unique genomic array system capable of simultaneously and specifically assaying the single copy transgenic human PRM domain in addition to the endogenous locus (Johnson et al. 2011). Utilizing these methods, similar studies have been reported in varied somatic cell types (Linnemann \& Krawetz 2009a, 2009b, Linnemann et al. 2007, 2009, Drennan et al. 2010). Preliminary analysis of the human sperm nuclear matrix from four donors has yielded intriguing results (Fig. 2A and B). Following extraction with $2 \mathrm{M} \mathrm{NaCl}$ and $10 \mathrm{mM}$ DTT, in the presence of $10 \mathrm{mM}$ EDTA, unconstrained DNA loops were released from isolated sperm nuclear matrices by EcoRI digestion. Matrix- and loop-associated DNA fractions were separated by centrifugation, labeled, and competitively hybridized to genomic tiling arrays. Analysis was confined to the PRM locus (Fig. 2). In agreement with previous studies, the coding regions of the domain reside within a nuclease-sensitive loop, which is anchored to the nuclear matrix by flanking S/MARs (Choudhary et al. 1995, Kramer \& Krawetz 1996). This conformation reflects the prior expressive status of the locus which first becomes potentiated in pachytene spermatocytes (Kramer et al. 2000). Interestingly, the S/MARs display a degree of variance between the donors (Fig. 2B) and are comparatively distal of those previously observed (Choudhary et al. 1995, Kramer \& Krawetz 1996). The majority of these regions show negligible sperm histone enrichment in contrast to the promoters and exons of the PRM locus. However, the large sequence block identified as the $3^{\prime}$ MAR in this study does appear to be strongly bound by nucleosomes, 
A
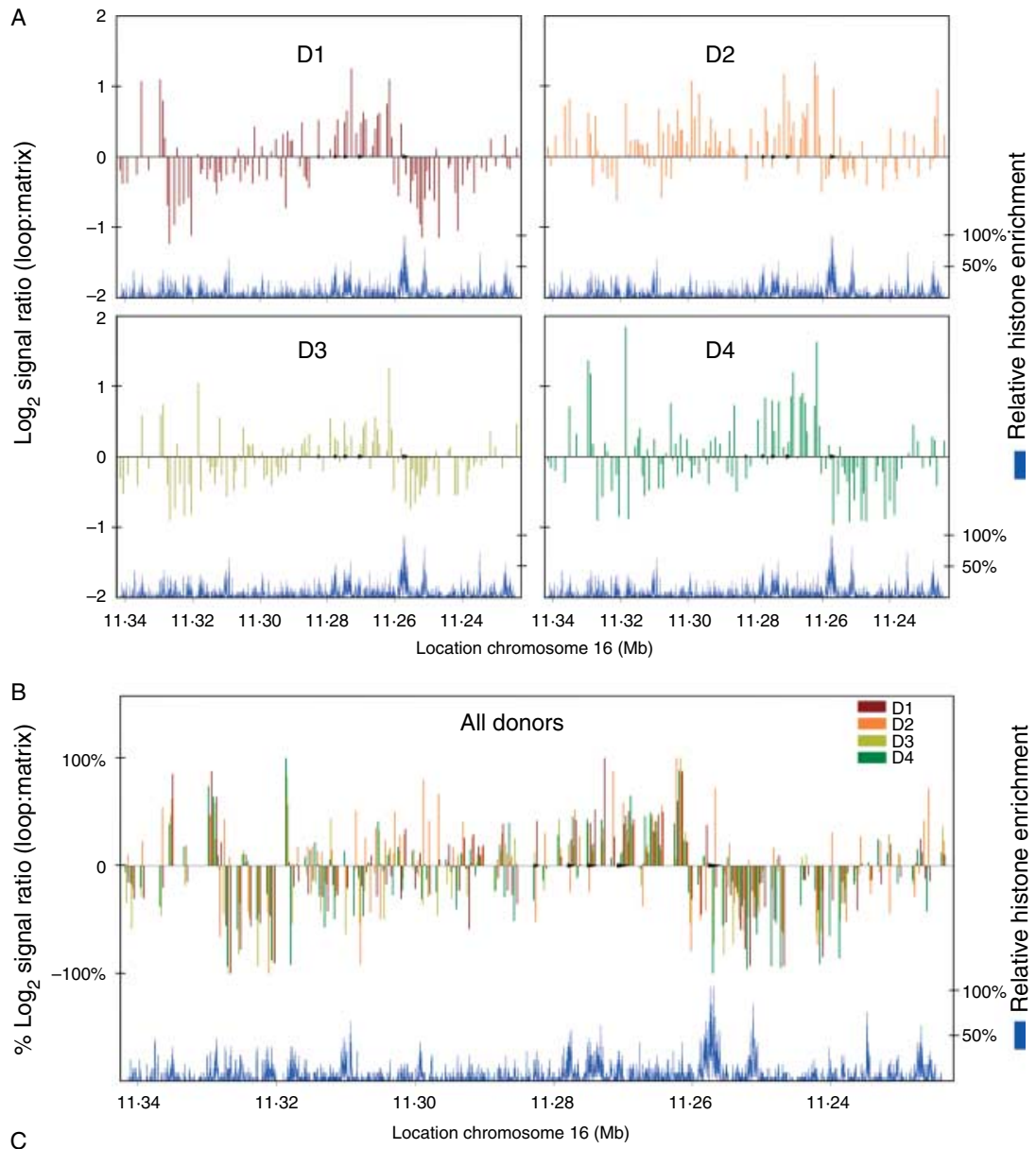

C

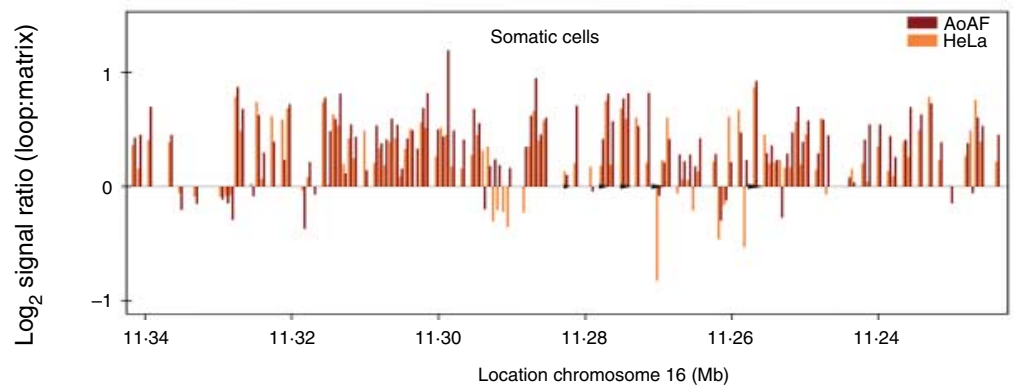

Figure 2 Nuclear matrix association within the protamine locus of sperm and somatic cells. Genomic regions in sperm associated with DNA loops or the nuclear matrix within a $\sim 120 \mathrm{~kb}$ region of human chromosome 16 (chr 16: 11223 803-11 341499 ) are displayed as $\log _{2}$ values (loop/matrix). This region contains the complete protamine domain as well as the neighboring SOCS1 gene. Genes are denoted by black arrows: $P R M 1>P R M 2>P R M 3>T N P 2>$

$S O C S$. The relative histone enrichment across this region is illustrated in blue (GEO Series GSE15690, http://www.ncbi.nlm.nih.gov/geo/ query/acc.cgi?acc = GSE15690). (A) Nuclear matrices were extracted from sperm from four fertile donors. Following EcoRI digestion, matrixand loop-associated DNA fractions were labeled and competitively hybridized to Nimblegen CGAR0150-WHG8 CGH arrays. Loop- or matrixassociation was determined as previously described (Linnemann et al. 2007). (B) Composite of percent normalized values from all four fertile donors. (C) Loop- and matrix-associated DNA fractions from HeLa and AoAF cells were identified as previously described (Linnemann \& Krawetz 2009a, 2009b, Linnemann et al. 2009). though this is likely due to the presence of the SOCS1 promoter. This entire region shares a high degree of synteny with sequence downstream of the mouse PRM domain which functions as a MAR in spermatids (Martins \& Krawetz 2007a). This region also contains a $3^{\prime}$ boundary element that is essential for full expression of the human PRM genes (Martins et al. 2004). Mutations in this region have been correlated with decreased PRM expression and infertility in men (Kramer et al. 1997). Furthermore, deletion of this element in transgenic mice harboring a copy of the human PRM locus recapitulates this perturbed PRM expression (Martins et al. 2004). Irrespective of the above, nuclear matrix association within this region clearly differs from that observed in somatic cells (Fig. 2, Linnemann \& Krawetz 2009a, $2009 b$, Linnemann et al. 2009). Studies of higher order chromatin structure within the orthologous domains of this transgenic model will inform the degree to which this regulation is species specific.

\section{Conclusion}

The appreciation that sperm functionally package several layers of developmentally important information has become apparent. In human sperm, the genomic landscape, though dominated by PRMs, is enriched in 
histones at both promoters and exons. The presence of nucleosomes in these regions, some of which contain modified histones, is highly suggestive of subsequent epigenetic control in the embryo. Furthermore, nucleosome-associated DNA may also tether individual toroid loops to the nuclear matrix. Following fertilization, these sequences partnered with the sperm nuclear matrix may provide the zygote a platform for the transgenerational inheritance of paternal chromatin structure. These potentially inherited chromatin associations may demarcate replicons utilized in early development. Perhaps some of these events are directed by factors translated from paternally derived mRNAs. This subpopulation of RNAs, like the rest of the transcripts present in sperm, is undoubtedly delivered to the oocyte. But are these transcripts functional?

The nuclear environment of the mammalian sperm continues to yield new discoveries. Many of these will be instrumental in elucidating the mechanisms controlling the early moments following conception. However, this will require the use of non-human models. Irrespectively, male fertility biomarkers may soon emerge as local chromatin structure and/or RNA signatures continue to be developed.

\section{Declaration of interest}

The authors declare that there is no conflict of interest that could be perceived as prejudicing the impartiality of the review reported.

\section{Funding}

This work is supported in part by the NIH grant HD36512, the Presidential Research Enhancement Program in Computational Biology, and the Charlotte B Failing Professorship to S A Krawetz.

\section{Acknowledgements}

The authors would like to thank Dr Doug T Carrell at the University of Utah, School of Medicine, for the provision of human semen samples. We thank all of those who have contributed to the field and apologize to those colleagues whose work was omitted due to space limitations.

\section{References}

Adenot PG, Mercier Y, Renard JP \& Thompson EM 1997 Differential H4 acetylation of paternal and maternal chromatin precedes DNA replication and differential transcriptional activity in pronuclei of 1-cell mouse embryos. Development 124 4615-4625.

Adom JN \& Richard-Foy H 1991 A region immediately adjacent to the origin of replication of bovine papilloma virus type 1 interacts in vitro with the nuclear matrix. Biochemical and Biophysical Research Communications 176 479-485. (doi:10.1016/0006-291X(91)90949-8)

Aitken RJ \& Koppers AJ 2011 Apoptosis and DNA damage in human spermatozoa. Asian Journal of Andrology [in press]. (doi:10.1038/aja. 2010.68)
Albrethsen J, Knol JC \& Jimenez CR 2009 Unravelling the nuclear matrix proteome. Journal of Proteomics 72 71-81. (doi:10.1016/j.jprot.2008. 09.005)

Amanai M, Brahmajosyula M \& Perry AC 2006 A restricted role for spermborne microRNAs in mammalian fertilization. Biology of Reproduction 75 877-884. (doi:10.1095/biolreprod.106.056499)

Anachkova B, Djeliova V \& Russev G 2005 Nuclear matrix support of DNA replication. Journal of Cellular Biochemistry 96 951-961. (doi:10.1002/ jcb.20610)

Ankem MK, Mayer E, Ward WS, Cummings KB \& Barone JG 2002 Novel assay for determining DNA organization in human spermatozoa: implications for male factor infertility. Urology 59 575-578. (doi:10. 1016/S0090-4295(01)01619-3)

Aoki F, Worrad DM \& Schultz RM 1997 Regulation of transcriptional activity during the first and second cell cycles in the preimplantation mouse embryo. Developmental Biology 181 296-307. (doi:10.1006/ dbio.1996.8466)

Arpanahi A, Brinkworth M, Iles D, Krawetz SA, Paradowska A, Platts AE, Saida M, Steger K, Tedder P \& Miller D 2009 Endonuclease-sensitive regions of human spermatozoal chromatin are highly enriched in promoter and CTCF binding sequences. Genome Research 19 1338-1349. (doi:10.1101/gr.094953.109)

Avendano C, Franchi A, Jones E \& Oehninger S 2009 Pregnancy-specific $\beta$-1-glycoprotein 1 and human leukocyte antigen-E mRNA in human sperm: differential expression in fertile and infertile men and evidence of a possible functional role during early development. Human Reproduction 24 270-277. (doi:10.1093/humrep/den381)

Awe S \& Renkawitz-Pohl R 2010 Histone H4 acetylation is essential to proceed from a histone- to a protamine-based chromatin structure in spermatid nuclei of Drosophila melanogaster. Systems Biology in Reproductive Medicine 56 44-61. (doi:10.3109/193963609034 90790)

Baarends W, Hoogerbrugge J, Roest H, Ooms M, Vreeburg J, Hoeijmakers J \& Grootegoed J 1999 Histone ubiquitination and chromatin remodeling in mouse spermatogenesis. Developmental Biology 207 322-333. (doi:10.1006/dbio.1998.9155)

Baker MA \& Aitken RJ 2009 Proteomic insights into spermatozoa: critiques, comments and concerns. Expert Review of Proteomics 6 691-705. (doi:10.1586/epr.09.76)

Baker MA, Hetherington L, Reeves GM \& Aitken RJ 2008 The mouse sperm proteome characterized via IPG strip prefractionation and LC-MS/MS identification. Proteomics 8 1720-1730. (doi:10.1002/pmic.200701020)

Balhorn R 2007 The protamine family of sperm nuclear proteins. Genome Biology 8 227. (doi:10.1186/gb-2007-8-9-227)

Balhorn R, Gledhill BL \& Wyrobek AJ 1977 Mouse sperm chromatin proteins: quantitative isolation and partial characterization. Biochemistry 16 4074-4080. (doi:10.1021/bi00637a021)

Balhorn R, Weston S, Thomas C \& Wyrobek A 1984 DNA packaging in mouse spermatids. Synthesis of protamine variants and four transition proteins. Experimental Cell Research 150 298-308. (doi:10.1016/00144827(84)90572-X)

Banerjee S \& Smallwood A 1998 Chromatin modification of imprinted $\mathrm{H} 19$ gene in mammalian spermatozoa. Molecular Reproduction and Development 50 474-484. (doi:10.1002/(SICI)1098-2795(199808)50:4 $<474::$ AID-MRD11>3.0.CO;2-2)

Barone JG, De Lara J, Cummings KB \& Ward WS 1994 DNA organization in human spermatozoa. Journal of Andrology 15 139-144.

Barone JG, Christiano AP \& Ward WS 2000 DNA organization in patients with a history of cryptorchidism. Urology 56 1068-1070. (doi:10.1016/ S0090-4295(00)00788-3)

Barratt CL, Aitken RJ, Bjorndahl L, Carrell DT, de Boer P, Kvist U, Lewis SE, Perreault SD, Perry MJ, Ramos L et al. 2010 Sperm DNA: organization, protection and vulnerability: from basic science to clinical applications a position report. Human Reproduction 25 824-838. (doi:10.1093/ humrep/dep465)

Bayer M, Nawy T, Giglione C, Galli M, Meinnel T \& Lukowitz W 2009 Paternal control of embryonic patterning in Arabidopsis thaliana. Science 323 1485-1488. (doi:10.1126/science.1167784)

Berezney R \& Coffey DS 1977 Nuclear matrix. Isolation and characterization of a framework structure from rat liver nuclei. Journal of Cell Biology 73 616-637. (doi:10.1083/jcb.73.3.616) 
Bizzaro D, Manicardi G, Bianchi PG \& Sakkas D 2000 Sperm decondensation during fertilisation in the mouse: presence of DNase I hypersensitive sites in situ and a putative role for topoisomerase II. Zygote 8 197-202. (doi:10.1017/S0967199400000988)

de Boer P, Ramos L, de Vries M \& Gochhait S 2010 Memoirs of an insult: sperm as a possible source of transgenerational epimutations and genetic instability. Molecular Human Reproduction 16 48-56. (doi:10.1093/ molehr/gap098)

Braude P, Bolton V \& Moore S 1988 Human gene expression first occurs between the four- and eight-cell stages of preimplantation development. Nature 332 459-461. (doi:10.1038/332459a0)

Braun RE 2001 Packaging paternal chromosomes with protamine. Nature Genetics 28 10-12. (doi:10.1038/88194)

Brykczynska U, Hisano M, Erkek S, Ramos L, Oakeley EJ, Roloff TC, Beisel C, Schubeler D, Stadler MB \& Peters AH 2010 Repressive and active histone methylation mark distinct promoters in human and mouse spermatozoa. Nature Structural and Molecular Biology 17 679-687. (doi:10.1038/nsmb.1821)

Butler MG 2009 Genomic imprinting disorders in humans: a mini-review. Journal of Assisted Reproduction and Genetics 26 477-486. (doi:10. 1007/s10815-009-9353-3)

Carrell DT \& Hammoud SS 2010 The human sperm epigenome and its potential role in embryonic development. Molecular Human Reproduction 16 37-47. (doi:10.1093/molehr/gap090)

Carrey EA, Dietz C, Glubb DM, Loffler M, Lucocq JM \& Watson PF 2002 Detection and location of the enzymes of de novo pyrimidine biosynthesis in mammalian spermatozoa. Reproduction 123 757-768. (doi:10.1530/rep.0.1230757)

Chadwick BP \& Willard HF 2001 A novel chromatin protein, distantly related to histone $\mathrm{H} 2 \mathrm{~A}$, is largely excluded from the inactive $X$ chromosome. Journal of Cell Biology 152 375-384. (doi:10.1083/jcb. 152.2.375)

Chen H, Sun J, Zhang Y, Davie J \& Meistrich M 1998 Ubiquitination of histone $\mathrm{H} 3$ in elongating spermatids of rat testes. Journal of Biological Chemistry 273 13165-13169. (doi:10.1074/jbc.273.21.13165)

Choudhary SK, Wykes SM, Kramer JA, Mohamed AN, Koppitch F, Nelson JE \& Krawetz SA 1995 A haploid expressed gene cluster exists as a single chromatin domain in human sperm. Journal of Biological Chemistry 270 8755-8762. (doi:10.1074/jbc.270.15.8755)

Christensen ME, Rattner JB \& Dixon GH 1984 Hyperacetylation of histone $\mathrm{H} 4$ promotes chromatin decondensation prior to histone replacement by protamines during spermatogenesis in rainbow trout. Nucleic Acids Research 12 4575-4592. (doi:10.1093/nar/12.11.4575)

Churikov D, Siino J, Svetlova M, Zhang K, Gineitis A, Morton Bradbury E \& Zalensky A 2004a Novel human testis-specific histone H2B encoded by the interrupted gene on the X chromosome. Genomics 84 745-756. (doi:10.1016/j.ygeno.2004.06.001)

Churikov D, Zalenskaya IA \& Zalensky AO 2004b Male germline-specific histones in mouse and man. Cytogenetic and Genome Research 105 203-214. (doi:10.1159/000078190)

Codrington AM, Hales BF \& Robaire B 2004 Spermiogenic germ cell phasespecific DNA damage following cyclophosphamide exposure. Journal of Andrology 25 354-362.

Codrington AM, Hales BF \& Robaire B 2007a Chronic cyclophosphamide exposure alters the profile of rat sperm nuclear matrix proteins. Biology of Reproduction 77 303-311. (doi:10.1095/biolreprod.107.060244)

Codrington AM, Hales BF \& Robaire B 2007 $b$ Exposure of male rats to cyclophosphamide alters the chromatin structure and basic proteome in spermatozoa. Human Reproduction 22 1431-1442. (doi:10.1093/ humrep/dem002)

Comings DE \& Okada TA 1976 Nuclear proteins. III. The fibrillar nature of the nuclear matrix. Experimental Cell Research 103 341-360. (doi:10. 1016/0014-4827(76)90271-8)

Cook PR \& Brazell IA 1975 Supercoils in human DNA. Journal of Cell Science 19 261-279.

Courbet S, Gay S, Arnoult N, Wronka G, Anglana M, Brison O \& Debatisse M 2008 Replication fork movement sets chromatin loop size and origin choice in mammalian cells. Nature 455 557-560. (doi:10. 1038/nature07233)

Csordas A 1990 On the biological role of histone acetylation. Biochemical Journal 265 23-38.
Curry E, Ellis SE \& Pratt SL 2009 Detection of porcine sperm microRNAs using a heterologous microRNA microarray and reverse transcriptase polymerase chain reaction. Molecular Reproduction and Development 76 218-219. (doi:10.1002/mrd.20980)

Deng W \& Lin H 2002 Miwi, a murine homolog of piwi, encodes a cytoplasmic protein essential for spermatogenesis. Developmental Cel/ 2 819-830. (doi:10.1016/S1534-5807(02)00165-X)

Depa-Martynow M, Kempisty B, Lianeri M, Jagodzinski PP \& Jedrzejczak P 2007 Association between fertilin beta, protamines 1 and 2 and spermatid-specific linker histone H1-like protein mRNA levels, fertilization ability of human spermatozoa, and quality of preimplantation embryos. Folia Histochemistry and Cytobiology 45 (Supplement 1) S79-S85.

Drennan KJ, Linnemann AK, Platts AE, Heng HH, Armant DR \& Krawetz SA 2010 Nuclear matrix association: switching to the invasive cytotrophoblast. Placenta 31 365-372. (doi:10.1016/j.placenta.2010.02.012)

Erhardt S, Su IH, Schneider R, Barton S, Bannister AJ, Perez-Burgos L, Jenuwein T, Kouzarides T, Tarakhovsky A \& Surani MA 2003 Consequences of the depletion of zygotic and embryonic enhancer of zeste 2 during preimplantation mouse development. Development 130 4235-4248. (doi:10.1242/dev.00625)

Fenic I, Sonnack V, Failing K, Bergmann M \& Steger K 2004 In vivo effects of histone-deacetylase inhibitor trichostatin-A on murine spermatogenesis. Journal of Andrology 25 811-818.

Fey EG, Wan KM \& Penman S 1984 Epithelial cytoskeletal framework and nuclear matrix-intermediate filament scaffold: three-dimensional organization and protein composition. Journal of Cell Biology 98 1973-1984. (doi:10.1083/jcb.98.6.1973)

Foster HA, Abeydeera LR, Griffin DK \& Bridger JM 2005 Non-random chromosome positioning in mammalian sperm nuclei, with migration of the sex chromosomes during late spermatogenesis. Journal of Cell Science 118 1811-1820. (doi:10.1242/jcs.02301)

Garcia-Herrero S, Garrido N, Martinez-Conejero JA, Remohi J, Pellicer A \& Meseguer M 2010 Ontological evaluation of transcriptional differences between sperm of infertile males and fertile donors using microarray analysis. Journal of Assisted Reproduction and Genetics 27 111-120. (doi:10.1007/s10815-010-9388-5)

Gardiner-Garden M, Ballesteros M, Gordon M \& Tam PP 1998 Histoneand protamine-DNA association: conservation of different patterns within the $\beta$-globin domain in human sperm. Molecular and Cellular Biology 18 3350-3356.

Gatewood JM, Cook GR, Balhorn R, Bradbury EM \& Schmid CW 1987 Sequence-specific packaging of DNA in human sperm chromatin. Science 236 962-964. (doi:10.1126/science.3576213)

Gatewood JM, Cook GR, Balhorn R, Schmid CW \& Bradbury EM 1990 Isolation of four core histones from human sperm chromatin representing a minor subset of somatic histones. Journal of Biological Chemistry 265 20662-20666.

Ghildiyal M \& Zamore PD 2009 Small silencing RNAs: an expanding universe. Nature Reviews. Genetics 10 94-108. (doi:10.1038/nrg2504)

Gilbert I, Bissonnette N, Boissonneault G, Vallee M \& Robert C 2007 A molecular analysis of the population of mRNA in bovine spermatozoa. Reproduction 133 1073-1086. (doi:10.1530/REP-06-0292)

Gineitis AA, Zalenskaya IA, Yau PM, Bradbury EM \& Zalensky AO 2000 Human sperm telomere-binding complex involves histone $\mathrm{H} 2 \mathrm{~B}$ and secures telomere membrane attachment. Journal of Cell Biology $\mathbf{1 5 1}$ 1591-1598. (doi:10.1083/jcb.151.7.1591)

Godmann M, Auger V, Ferraroni-Aguiar V, Di Sauro A, Sette C, Behr R \& Kimmins S 2007 Dynamic regulation of histone H3 methylation at lysine 4 in mammalian spermatogenesis. Biology of Reproduction 77 754-764. (doi:10.1095/biolreprod.107.062265)

Golan R, Cooper TG, Oschry Y, Oberpenning F, Schulze H, Shochat L \& Lewin LM 1996 Changes in chromatin condensation of human spermatozoa during epididymal transit as determined by flow cytometry. Human Reproduction 11 1457-1462.

Gomendio M, Malo AF, Garde J \& Roldan ER 2007 Sperm traits and male fertility in natural populations. Reproduction 134 19-29. (doi:10.1530/ REP-07-0143)

Govin J, Escoffier E, Rousseaux S, Kuhn L, Ferro M, Thévenon J, Catena R, Davidson I, Garin J, Khochbin S et al. 2007 Pericentric heterochromatin reprogramming by new histone variants during mouse spermiogenesis. Journal of Cell Biology 176 283-294. (doi:10.1083/jcb.200604141) 
Grandjean V, Gounon P, Wagner N, Martin L, Wagner KD, Bernex F, Cuzin F \& Rassoulzadegan M 2009 The miR-124-Sox9 paramutation: RNA-mediated epigenetic control of embryonic and adult growth. Development 136 3647-3655. (doi:10.1242/dev.041061)

Grenier L, Robaire B \& Hales BF 2010 Paternal exposure to cyclophosphamide affects the progression of sperm chromatin decondensation and activates a DNA damage response in the prepronuclear rat zygote. Biology of Reproduction 83 195-204. (doi:10.1095/biolreprod.109. 083345)

Grimes S \& Henderson N 1984 Hyperacetylation of histone H4 in rat testis spermatids. Experimental Cell Research 152 91-97. (doi:10.1016/ 0014-4827(84)90232-5)

Gusse $M$, Sautière $P$, Bélaiche $D$, Martinage A, Roux $C$, Dadoune JP \& Chevaillier P 1986 Purification and characterization of nuclear basic proteins of human sperm. Biochimica et Biophysica Acta 884 124-134. (doi:10.1016/0304-4165(86)90235-7)

Hammoud SS, Nix DA, Zhang H, Purwar J, Carrell DT \& Cairns BR 2009 Distinctive chromatin in human sperm packages genes for embryo development. Nature 460 473-478. (doi:10.1038/nature08162)

Harrouk W, Codrington A, Vinson R, Robaire B \& Hales BF 2000a Paternal exposure to cyclophosphamide induces DNA damage and alters the expression of DNA repair genes in the rat preimplantation embryo. Mutation Research 461 229-241. (doi:10.1016/S0921-8777 (00)00053-7)

Harrouk W, Khatabaksh S, Robaire B \& Hales BF 2000b Paternal exposure to cyclophosphamide dysregulates the gene activation program in rat preimplantation embryos. Molecular Reproduction and Development $\mathbf{5 7}$ 214-223. (doi:10.1002/1098-2795(200011)57:3<214::AID-MRD2>3. $0 . \mathrm{CO} ; 2-\mathrm{D})$

Harrouk W, Robaire B \& Hales BF 2000c Paternal exposure to cyclophosphamide alters cell-cell contacts and activation of embryonic transcription in the preimplantation rat embryo. Biology of Reproduction 63 74-81. (doi:10.1095/biolreprod63.1.74)

Har-Vardi I, Mali R, Breietman M, Sonin Y, Albotiano S, Levitas E, Potashnik G \& Priel E 2007 DNA topoisomerases I and II in human mature sperm cells: characterization and unique properties. Human Reproduction 22 2183-2189. (doi:10.1093/humrep/dem170)

Hazzouri M, Rousseaux S, Mongelard F, Usson Y, Pelletier R, Faure AK, Vourc'h C \& Sele B 2000 Genome organization in the human sperm nucleus studied by FISH and confocal microscopy. Molecular Reproduction and Development 55 307-315. (doi:10.1002/(SICI)10982795(200003) 55:3<307::AID-MRD9> 3.0.CO;2-P)

van der Heijden GW, Dieker JW, Derijck AA, Muller S, Berden JH, Braat DD, van der Vlag J \& de Boer P 2005 Asymmetry in histone H3 variants and lysine methylation between paternal and maternal chromatin of the early mouse zygote. Mechanisms of Development 122 1008-1022. (doi:10.1016/j.mod.2005.04.009)

van der Heijden GW, Derijck AA, Ramos L, Giele M, van der Vlag J \& de Boer P 2006 Transmission of modified nucleosomes from the mouse male germline to the zygote and subsequent remodeling of paternal chromatin. Developmental Biology 298 458-469. (doi:10.1016/j.ydbio. 2006.06.051)

van der Heijden GW, Ramos L, Baart EB, van den Berg IM, Derijck AA, van der Vlag J, Martini E \& de Boer P 2008 Sperm-derived histones contribute to zygotic chromatin in humans. BMC Developmental Biology 8 34. (doi:10.1186/1471-213X-8-34)

van der Heijden GW, van den Berg IM, Baart EB, Derijck AA, Martini E \& de Boer P 2009 Parental origin of chromatin in human monopronuclear zygotes revealed by asymmetric histone methylation patterns, differs between IVF and ICSI. Molecular Reproduction and Development $\mathbf{7 6}$ 101-108. (doi:10.1002/mrd.20933)

Heng HH, Goetze S, Ye CJ, Liu G, Stevens JB, Bremer SW, Wykes SM, Bode J \& Krawetz SA 2004 Chromatin loops are selectively anchored using scaffold/matrix-attachment regions. Journal of Cell Science $\mathbf{1 1 7}$ 999-1008. (doi:10.1242/jcs.00976)

Hud NV, Allen MJ, Downing KH, Lee J \& Balhorn R 1993 Identification of the elemental packing unit of DNA in mammalian sperm cells by atomic force microscopy. Biochemical and Biophysical Research Communications 193 1347-1354. (doi:10.1006/bbrc.1993.1773)

Jedrzejczak P, Kempisty B, Bryja A, Mostowska M, Depa-Martynow M, Pawelczyk L \& Jagodzinski PP 2007 Quantitative assessment of transition proteins 1, 2 spermatid-specific linker histone $\mathrm{H}$ 1-like protein transcripts in spermatozoa from normozoospermic and asthenozoospermic men. Archives of Andrology 53 199-205. (doi:10.1080/01485010701426430)

Johnson GD, Platts AE, Lalancette C, Goodrich R \& Krawetz SA 2011 Interrogating the transgenic genome: development of an interspecies tiling array. Systems Biology in Reproductive Medicine [in press].

Kanhere A, Viiri K, Araujo CC, Rasaiyaah J, Bouwman RD, Whyte WA, Pereira CF, Brookes E, Walker K, Bell GW et al. 2010 Short RNAs are transcribed from repressed polycomb target genes and interact with polycomb repressive complex-2. Molecular Cell 38 675-688. (doi:10.1016/j.molcel.2010.03.019)

Kawahara M, Wu Q, Takahashi N, Morita S, Yamada K, Ito M, FergusonSmith AC \& Kono T 2007 High-frequency generation of viable mice from engineered bi-maternal embryos. Nature Biotechnology 25 1045-1050. (doi:10.1038/nbt1331)

Kierszenbaum AL \& Tres LL 1975 Structural and transcriptional features of the mouse spermatid genome. Journal of Cell Biology 65 258-270. (doi:10.1083/jcb.65.2.258)

Kim DH, Saetrom P, Snove O Jr \& Rossi JJ 2008 MicroRNA-directed transcriptional gene silencing in mammalian cells. PNAS $\mathbf{1 0 5}$ 16230-16235. (doi:10.1073/pnas.0808830105)

Kimmins S \& Sassone-Corsi P 2005 Chromatin remodelling and epigenetic features of germ cells. Nature 434 583-589. (doi:10.1038/nature03368)

Klattenhoff C \& Theurkauf W 2008 Biogenesis and germline functions of piRNAs. Development 135 3-9. (doi:10.1242/dev.006486)

Klaus AV, McCarrey JR, Farkas A \& Ward WS 2001 Changes in DNA loop domain structure during spermatogenesis and embryogenesis in the Syrian golden hamster. Biology of Reproduction 64 1297-1306. (doi:10. 1095/biolreprod64.5.1297)

Kleene KC 1989 Poly (A) shortening accompanies the activation of translation of five mRNAs during spermiogenesis in the mouse. Development 106 367-373.

Kocabas AM, Crosby J, Ross PJ, Otu HH, Beyhan Z, Can H, Tam WL, Rosa GJ, Halgren RG, Lim B et al. 2006 The transcriptome of human oocytes. PNAS 103 14027-14032. (doi:10.1073/pnas.0603227103)

Kono T, Obata Y, Wu Q, Niwa K, Ono Y, Yamamoto Y, Park ES, Seo JS \& Ogawa H 2004 Birth of parthenogenetic mice that can develop to adulthood. Nature 428 860-864. (doi:10.1038/nature02402)

Kramer JA \& Krawetz SA 1996 Nuclear matrix interactions within the sperm genome. Journal of Biological Chemistry 271 11619-11622. (doi:10. 1074/jbc.271.37.22915)

Kramer JA, Zhang S, Yaron Y, Zhao Y \& Krawetz SA 1997 Genetic testing for male infertility: a postulated role for mutations in sperm nuclear matrix attachment regions. Genetic Testing 1 125-129. (doi:10.1089/gte. 1997.1.125)

Kramer JA, McCarrey JR, Djakiew D \& Krawetz SA 2000 Human spermatogenesis as a model to examine gene potentiation. Molecular Reproduction and Development 56 254-258. (doi:10.1002/(SICI)10982795(200006)56:2 + <254::AID-MRD9>3.0.CO;2-\#)

Krawetz SA 2005 Paternal contribution: new insights and future challenges. Nature Reviews. Genetics 6 633-642. (doi:10.1038/nrg1654)

Krishnamoorthy T, Chen X, Govin J, Cheung W, Dorsey J, Schindler K, Winter E, Allis C, Guacci V \& Khochbin S 2006 Phosphorylation of histone $\mathrm{H} 4 \mathrm{Ser} 1$ regulates sporulation in yeast and is conserved in fly and mouse spermatogenesis. Genes and Development 20 2580. (doi:10. 1101/gad.1457006)

Kuramochi-Miyagawa S, Kimura T, Ijiri TW, Isobe T, Asada N, Fujita $Y$, Ikawa M, Iwai N, Okabe M, Deng W et al. 2004 Mili, a mammalian member of piwi family gene, is essential for spermatogenesis. Development 131 839-849. (doi:10.1242/dev.00973)

Kuretake S, Kimura Y, Hoshi K \& Yanagimachi R 1996 Fertilization and development of mouse oocytes injected with isolated sperm heads. Biology of Reproduction 55 789-795. (doi:10.1095/biolreprod55.4.789)

Kurtz K, Martinez-Soler F, Ausio J \& Chiva M 2007 Acetylation of histone $\mathrm{H} 4$ in complex structural transitions of spermiogenic chromatin. Journal of Cellular Biochemistry 102 1432-1441. (doi:10.1002/jcb. 21365)

Kwon YK \& Hecht NB 1993 Binding of a phosphoprotein to the $3^{\prime}$ untranslated region of the mouse protamine 2 mRNA temporally represses its translation. Molecular and Cellular Biology 13 6547-6557. 
Lalancette C, Miller D, Li Y \& Krawetz SA 2008 Paternal contributions: new functional insights for spermatozoal RNA. Journal of Cellular Biochemistry 104 1570-1579. (doi:10.1002/jcb.21756)

Lalancette C, Platts AE, Johnson GD, Emery BR, Carrell DT \& Krawetz SA 2009 Identification of human sperm transcripts as candidate markers of male fertility. Journal of Molecular Medicine 87 735-748. (doi:10.1007/ s00109-009-0485-9)

Lau NC 2010 Small RNAs in the animal gonad: guarding genomes and guiding development. International Journal of Biochemistry and Cell Biology 42 1334-1347. (doi:10.1016/j.biocel.2010.03.005)

Lawrence C 1994 The RAD6 DNA repair pathway in Saccharomyces cerevisiae: what does it do, and how does it do it? BioEssays 16 253-258. (doi:10.1002/bies.950160408)

Leduc F, Maquennehan V, Nkoma GB \& Boissonneault G 2008a DNA damage response during chromatin remodeling in elongating spermatids of mice. Biology of Reproduction 78 324-332. (doi:10.1095/biolreprod. 107.064162)

Leduc F, Nkoma GB \& Boissonneault G 2008b Spermiogenesis and DNA repair: a possible etiology of human infertility and genetic disorders. Systems Biology in Reproductive Medicine 54 3-10. (doi:10.1080/ 19396360701876823)

Lee K, Haugen HS, Clegg CH \& Braun RE 1995 Premature translation of protamine $1 \mathrm{mRNA}$ causes precocious nuclear condensation and arrests spermatid differentiation in mice. PNAS 92 12451-12455. (doi:10.1073/ pnas.92.26.12451)

Lefievre L, Bedu-Addo K, Conner SJ, Machado-Oliveira GS, Chen Y, Kirkman-Brown JC, Afnan MA, Publicover SJ, Ford WC \& Barratt CL 2007 Counting sperm does not add up any more: time for a new equation? Reproduction 133 675-684. (doi:10.1530/REP-06-0332)

Lemaitre JM, Danis E, Pasero P, Vassetzky Y \& Mechali M 2005 Mitotic remodeling of the replicon and chromosome structure. Cell $\mathbf{1 2 3}$ 787-801. (doi:10.1016/j.cell.2005.08.045)

Lewis SE 2007 Is sperm evaluation useful in predicting human fertility? Reproduction 134 31-40. (doi:10.1530/REP-07-0152)

Lewis SE, Agbaje I \& Alvarez J 2008 Sperm DNA tests as useful adjuncts to semen analysis. Systems Biology in Reproductive Medicine 54 111-125. (doi:10.1080/19396360801957739)

Li Y, Lalancette C, Miller D \& Krawetz SA 2008 Characterization of nucleohistone and nucleoprotamine components in the mature human sperm nucleus. Asian Journal of Andrology 10 535-541. (doi:10.1111/j. 1745-7262.2008.00410.x)

Linnemann AK \& Krawetz SA 2009a Silencing by nuclear matrix attachment distinguishes cell-type specificity: association with increased proliferation capacity. Nucleic Acids Research 37 2779-2788. (doi:10. 1093/nar/gkp135)

Linnemann AK \& Krawetz SA 2009b Maintenance of a functional higher order chromatin structure: the role of the nuclear matrix in normal and disease states. Gene Therapy \& Molecular Biology 13 231-243.

Linnemann AK, Platts AE, Doggett N, Gluch A, Bode J \& Krawetz SA 2007 Genomewide identification of nuclear matrix attachment regions: an analysis of methods. Biochemical Society Transactions 35 612-617. (doi:10.1042/BST0350612)

Linnemann AK, Platts AE \& Krawetz SA 2009 Differential nuclear scaffold/matrix attachment marks expressed genes. Human Molecular Genetics 18 645-654. (doi:10.1093/hmg/ddn394)

Loppin B, Bonnefoy E, Anselme C, Laurencon A, Karr TL \& Couble P 2005 The histone $\mathrm{H} 3.3$ chaperone HIRA is essential for chromatin assembly in the male pronucleus. Nature 437 1386-1390. (doi:10.1038/nature04059)

Lu L-Y, Wu J, Ye L, Gavrilina GB, Saunders TL \& Yu X 2010 RNF8dependent histone modifications regulate nucleosome removal during spermatogenesis. Developmental Cell 18 371-384. (doi:10.1016/j. devcel.2010.01.010)

Ma J, Flemr M, Stein P, Berninger P, Malik R, Zavolan M, Svoboda P \& Schultz RM 2010 MicroRNA activity is suppressed in mouse oocytes. Current Biology 20 265-270. (doi:10.1016/j.cub.2009.12.042)

Malo AF, Gomendio M, Garde J, Lang-Lenton B, Soler AJ \& Roldan ER 2006 Sperm design and sperm function. Biology Letters 2 246-249. (doi:10. 1098/rsbl.2006.0449)

Malyavantham KS, Bhattacharya S, Barbeitos M, Mukherjee L, Xu J, Fackelmayer FO \& Berezney R 2008 Identifying functional neighborhoods within the cell nucleus: proximity analysis of early S-phase replicating chromatin domains to sites of transcription, RNA polymerase II, HP1 gamma, matrin 3 and SAF-A. Journal of Cellular Biochemistry 105 391-403. (doi:10.1002/jcb.21834)

Marcon L \& Boissonneault G 2004 Transient DNA strand breaks during mouse and human spermiogenesis new insights in stage specificity and link to chromatin remodeling. Biology of Reproduction 70 910-918. (doi:10.1095/biolreprod.103.022541)

Margueron R, Justin N, Ohno K, Sharpe ML, Son J, Drury WJ III, Voigt P, Martin SR, Taylor WR, De Marco V et al. 2009 Role of the polycomb protein EED in the propagation of repressive histone marks. Nature $\mathbf{4 6 1}$ 762-767. (doi:10.1038/nature08398)

Martins RP \& Krawetz SA 2007a Decondensing the protamine domain for transcription. PNAS 104 8340-8345. (doi:10.1073/pnas.0700076104)

Martins RP \& Krawetz SA $2007 b$ Nuclear organization of the protamine locus. Society of Reproduction and Fertility Supplement 64 1-12.

Martins RP, Ostermeier GC \& Krawetz SA 2004 Nuclear matrix interactions at the human protamine domain: a working model of potentiation. Journal of Biological Chemistry 279 51862-51868. (doi:10.1074/jbc. M409415200)

Meistrich ML, Bucci LR, Trostle-Weige PK \& Brock WA 1985 Histone variants in rat spermatogonia and primary spermatocytes. Developmental Biology 112 230-240. (doi:10.1016/0012-1606(85) 90137-X)

Meistrich M, Trostle-Weige P, Lin R, Bhatnagar Y \& Allis C 1992 Highly acetylated $\mathrm{H} 4$ is associated with histone displacement in rat spermatids. Molecular Reproduction and Development 31 170-181. (doi:10.1002/ mrd.1080310303)

Meyer-Ficca M, Scherthan H, Burkle A \& Meyer R 2005 Poly(ADPribosyl)ation during chromatin remodeling steps in rat spermiogenesis. Chromosoma 114 67-74. (doi:10.1007/s00412-005-0344-6)

Mika S \& Rost B 2005 NMPdb: database of nuclear matrix proteins. Nucleic Acids Research 33 D160-D163. (doi:10.1093/nar/gki132)

Miller D, Brinkworth M \& Iles D 2010 Paternal DNA packaging in spermatozoa: more than the sum of its parts? DNA, histones, protamines and epigenetics Reproduction 139 287-301. (doi:10.1530/ REP-09-0281)

Minami N, Suzuki T \& Tsukamoto S 2007 Zygotic gene activation and maternal factors in mammals. Journal of Reproduction and Development 53 707-715. (doi:10.1262/jrd.19029)

Moazed D 2009 Small RNAs in transcriptional gene silencing and genome defence. Nature 457 413-420. (doi:10.1038/nature07756)

Moldenhauer JS, Ostermeier GC, Johnson A, Diamond MP \& Krawetz SA 2003 Diagnosing male factor infertility using microarrays. Journal of Andrology 24 783-789.

Moss SB, Burnham BL \& Bellve AR 1993 The differential expression of lamin epitopes during mouse spermatogenesis. Molecular Reproduction and Development 34 164-174. (doi:10.1002/mrd.1080340208)

Mudrak O, Tomilin N \& Zalensky A 2005 Chromosome architecture in the decondensing human sperm nucleus. Journal of Cell Science $\mathbf{1 1 8}$ 4541-4550. (doi:10.1242/jcs.02581)

Nadeau JH 2009 Transgenerational genetic effects on phenotypic variation and disease risk. Human Molecular Genetics 18 R202-R210. (doi:10. 1093/hmg/ddp366)

Nadel B, de Lara J, Finkernagel SW \& Ward WS 1995 Cell-specific organization of the $5 \mathrm{~S}$ ribosomal RNA gene cluster DNA loop domains in spermatozoa and somatic cells. Biology of Reproduction 53 1222-1228. (doi:10.1095/biolreprod53.5.1222)

Nahkuri S, Taft RJ \& Mattick JS 2009 Nucleosomes are preferentially positioned at exons in somatic and sperm cells. Cell Cycle $83420-3424$.

Nixon B, Bielanowicz A, McLaughlin EA, Tanphaichitr N, Ensslin MA \& Aitken RJ 2009 Composition and significance of detergent resistant membranes in mouse spermatozoa. Journal of Cellular Physiology 218 122-134. (doi:10.1002/jcp.21575)

Ocampo J, Mondragon R, Roa-Espitia AL, Chiquete-Felix N, Salgado ZO \& Mujica A 2005 Actin, myosin, cytokeratins and spectrin are components of the guinea pig sperm nuclear matrix. Tissue \& Cell 37 293-308. (doi:10.1016/j.tice.2005.03.003)

O'Carroll D, Erhardt S, Pagani M, Barton SC, Surani MA \& Jenuwein T 2001 The polycomb-group gene Ezh2 is required for early mouse development. Molecular and Cellular Biology 21 4330-4336. (doi:10. 1128/MCB.21.13.4330-4336.2001) 
Oliva R \& Mezquita C 1982 Histone H4 hyperacetylation and rapid turnover of its acetyl groups in transcriptionally inactive rooster testis spermatids. Nucleic Acids Research 10 8049-8059. (doi:10.1093/nar/ 10.24.8049)

Oliva R, Martinez-Heredia J \& Estanyol JM 2008 Proteomics in the study of the sperm cell composition, differentiation and function. Systems Biology in Reproductive Medicine 54 23-36. (doi:10.1080/1939636070 1879595)

Ooi SL \& Henikoff S 2007 Germline histone dynamics and epigenetics. Current Opinion in Cell Biology 19 257-265. (doi:10.1016/j.ceb.2007. 04.015)

Ostermeier GC, Sargeant GA, Yandell BS, Evenson DP \& Parrish JJ 2001 Relationship of bull fertility to sperm nuclear shape. Journal of Andrology 22 595-603.

Ostermeier GC, Dix DJ, Miller D, Khatri P \& Krawetz SA 2002 Spermatozoal RNA profiles of normal fertile men. Lancet $\mathbf{3 6 0}$ 772-777. (doi:10.1016/S0140-6736(02)09899-9)

Ostermeier GC, Miller D, Huntriss JD, Diamond MP \& Krawetz SA 2004 Reproductive biology: delivering spermatozoan RNA to the oocyte. Nature 429 154. (doi:10.1038/429154a)

Ostermeier GC, Goodrich RJ, Moldenhauer JS, Diamond MP \& Krawetz SA 2005 A suite of novel human spermatozoal RNAs. Journal of Andrology $2670-74$.

Palmer DK, O'Day K \& Margolis RL 1990 The centromere specific histone CENP-A is selectively retained in discrete foci in mammalian sperm nuclei. Chromosoma 100 32-36. (doi:10.1007/BF00337600)

Papaioannou MD \& Nef S 2010 MicroRNAs in the testis: building up male fertility. Journal of Andrology 31 26-33. (doi:10.2164/jandrol.109. 008128)

Parrington J, Jones KT, Lai A \& Swann K 1999 The soluble sperm factor that causes $\mathrm{Ca}^{2+}$ release from sea-urchin (Lytechinus pictus) egg homogenates also triggers $\mathrm{Ca}^{2+}$ oscillations after injection into mouse eggs. Biochemical Journal 341 1-4. (doi:10.1042/0264-6021:3410001)

Petronis A 2010 Epigenetics as a unifying principle in the aetiology of complex traits and diseases. Nature 465 721-727. (doi:10.1038/ nature09230)

Pittoggi C, Renzi L, Zaccagnini G, Cimini D, Degrassi F, Giordano R, Magnano AR, Lorenzini R, Lavia P \& Spadafora C 1999 A fraction of mouse sperm chromatin is organized in nucleosomal hypersensitive domains enriched in retroposon DNA. Journal of Cell Science 112 3537-3548.

Pivot-Pajot C, Caron C, Govin J, Vion A, Rousseaux S \& Khochbin S 2003 Acetylation-dependent chromatin reorganization by BRDT, a testisspecific bromodomain-containing protein. Molecular and Cellular Biology 23 5354-5365. (doi:10.1128/MCB.23.15.5354-5365.2003)

Platts AE, Dix DJ, Chemes HE, Thompson KE, Goodrich R, Rockett JC, Rawe VY, Quintana S, Diamond MP, Strader LF et al. 2007 Success and failure in human spermatogenesis as revealed by teratozoospermic RNAs. Human Molecular Genetics 16 763-773. (doi:10.1093/hmg/ ddm012)

Platts AE, Lalancette C, Emery BR, Carrell DT \& Krawetz SA 2010 Disease progression and solid tumor survival: a transcriptome decoherence model. Molecular and Cellular Probes 24 53-60. (doi:10.1016/j.mcp. 2009.09.005)

Puschendorf M, Terranova R, Boutsma E, Mao X, Isono K, Brykczynska U, Kolb C, Otte AP, Koseki H, Orkin SH et al. 2008 PRC1 and Suv39h specify parental asymmetry at constitutive heterochromatin in early mouse embryos. Nature Genetics 40 411-420. (doi:10.1038/ng.99)

Rassoulzadegan M, Grandjean V, Gounon P, Vincent S, Gillot I \& Cuzin F 2006 RNA-mediated non-mendelian inheritance of an epigenetic change in the mouse. Nature 441 469-474. (doi:10.1038/nature04674)

Rathke C, Barckmann B, Burkhard S, Jayaramaiah-Raja S, Roote J \& Renkawitz-Pohl R 2010 Distinct functions of Mst77F and protamines in nuclear shaping and chromatin condensation during Drosophila spermiogenesis. European Journal of Cell Biology 89 326-338. (doi:10. 1016/j.ejcb.2009.09.001)

Roest HP, van Klaveren J, de Wit J, van Gurp CG, Koken MH, Vermey M, van Roijen JH, Hoogerbrugge JW, Vreeburg JT, Baarends WM et al. 1996 Inactivation of the HR6B ubiquitin-conjugating DNA repair enzyme in mice causes male sterility associated with chromatin modification. Cell 86 799-810. (doi:10.1016/S0092-8674(00)80154-3) van Roijen HJ, Ooms MP, Spaargaren MC, Baarends WM, Weber RF, Grootegoed JA \& Vreeburg JT 1998 Immunoexpression of testis-specific histone $2 \mathrm{~B}$ in human spermatozoa and testis tissue. Human Reproduction 13 1559-1566. (doi:10.1093/humrep/13.6.1559)

Rousseaux S \& Ferro M 2009 Epigenetics of spermiogenesis: combining in silico and proteomic approaches in the mouse model. In Bioinformatics for Systems Biology, 2nd edn, pp 105-117. Ed SA Krawetz. New York: Humana Press.

Rousseaux S, Reynoird N, Escoffier E, Thevenon J, Caron C \& Khochbin S 2008 Epigenetic reprogramming of the male genome during gametogenesis and in the zygote. Reproductive Biomedicine Online 16 492-503. (doi:10.1016/S1472-6483(10)60456-7)

Santos F, Peters AH, Otte AP, Reik W \& Dean W 2005 Dynamic chromatin modifications characterise the first cell cycle in mouse embryos. Developmental Biology 280 225-236. (doi:10.1016/j.ydbio.2005.01.025)

Schultz RM 2002 The molecular foundations of the maternal to zygotic transition in the preimplantation embryo. Human Reproduction Update 8 323-331. (doi:10.1093/humupd/8.4.323)

Seyedin SM \& Kistler WS 1980 Isolation and characterization of rat testis $\mathrm{H} 1 \mathrm{t}$. An $\mathrm{H} 1$ histone variant associated with spermatogenesis. Journal of Biological Chemistry 255 5949-5954.

Shaman JA, Prisztoka R \& Ward WS 2006 Topoisomerase IIB and an extracellular nuclease interact to digest sperm DNA in an apoptotic-like manner. Biology of Reproduction 75 741-748. (doi:10.1095/biolreprod. 106.055178)

Shaman JA, Yamauchi Y \& Ward WS 2007 The sperm nuclear matrix is required for paternal DNA replication. Journal of Cellular Biochemistry 102 680-688. (doi:10.1002/jcb.21321)

Shires A, Carpenter MP \& Chalkley R 1976 A cysteine-containing H2B-like histone found in mature mammalian testis. Journal of Biological Chemistry 251 4155-4158.

Sonnack V, Failing K, Bergmann M \& Steger K 2002 Expression of hyperacetylated histone $\mathrm{H} 4$ during normal and impaired human spermatogenesis. Andrologia 34 384-390. (doi:10.1046/j.1439-0272. 2002.00524.x)

Soon LL, Ausio J, Breed WG, Power JH \& Muller S 1997 Isolation of histones and related chromatin structures from spermatozoa nuclei of a dasyurid marsupial, Sminthopsis crassicaudata. Journal of Experimental Zoology 278 322-332. (doi:10.1002/(SICI)1097-010X(19970801)278:5 $<322:: A I D-J E Z 6>3.3$. CO;2-E)

Sotolongo B, Huang TT, Isenberger E \& Ward WS 2005 An endogenous nuclease in hamster, mouse, and human spermatozoa cleaves DNA into loop-sized fragments. Journal of Andrology 26 272-280.

St Pierre J, Wright DJ, Rowe TC \& Wright SJ 2002 DNA topoisomerase II distribution in mouse preimplantation embryos. Molecular Reproduction and Development 61 335-346. (doi:10.1002/mrd.10016)

Suh N, Baehner L, Moltzahn F, Melton C, Shenoy A, Chen J \& Blelloch R 2010 MicroRNA function is globally suppressed in mouse oocytes and early embryos. Current Biology 20 271-277. (doi:10.1016/j.cub.2009. 12.044)

Tagami H, Ray-Gallet D, Almouzni G \& Nakatani Y 2004 Histone H3.1 and H3.3 complexes mediate nucleosome assembly pathways dependent or independent of DNA synthesis. Cell 116 51-61. (doi:10.1016/S00928674(03)01064-X)

Tanaka H, Iguchi N, Isotani A, Kitamura K, Toyama Y, Matsuoka Y, Onishi M, Masai K, Maekawa M, Toshimori K et al. 2005 HANP1/H1T2, a novel histone $\mathrm{H} 1$-like protein involved in nuclear formation and sperm fertility. Molecular and Cellular Biology 25 7107-7119. (doi:10.1128/ MCB.25.16.7107-7119.2005)

Tanphaichitr N, Sobhon P, Taluppeth N \& Chalermisarachai P 1978 Basic nuclear proteins in testicular cells and ejaculated spermatozoa in man. Experimental Cell Research 117 347-356. (doi:10.1016/0014-4827 (78)90148-9)

Tateno H \& Kamiguchi Y 2004 Chromosome analysis of mouse one-cell androgenones derived from a sperm nucleus exposed to topoisomerase II inhibitors at pre- and post-fertilization stages. Mutation Research $\mathbf{5 5 6}$ 117-126.

Torres-Padilla ME, Bannister AJ, Hurd PJ, Kouzarides T \& ZernickaGoetz M 2006 Dynamic distribution of the replacement histone variant $\mathrm{H} 3.3$ in the mouse oocyte and preimplantation embryos. International Journal of Developmental Biology 50 455-461. (doi:10.1387/ijdb. $052073 \mathrm{mt})$ 
Vastenhouw NL, Zhang Y, Woods IG, Imam F, Regev A, Liu XS, Rinn J \& Schier AF 2010 Chromatin signature of embryonic pluripotency is established during genome activation. Nature 464 922-926. (doi:10.1038/nature08866)

Vogelstein B, Pardoll DM \& Coffey DS 1980 Supercoiled loops and eucaryotic DNA replication. Cell 22 79-85. (doi:10.1016/00928674(80)90156-7)

Ward WS 1993 Deoxyribonucleic acid loop domain tertiary structure in mammalian spermatozoa. Biology of Reproduction 48 1193-1201. (doi:10.1095/biolreprod48.6.1193)

Ward WS 2010 Function of sperm chromatin structural elements in fertilization and development. Molecular Human Reproduction 16 30-36. (doi:10.1093/molehr/gap080)

Ward WS, Partin AW \& Coffey DS 1989 DNA loop domains in mammalian spermatozoa. Chromosoma 98 153-159. (doi:10.1007/BF00329678)

Ward WS, Kimura Y \& Yanagimachi R 1999 An intact sperm nuclear matrix may be necessary for the mouse paternal genome to participate in embryonic development. Biology of Reproduction 60 702-706. (doi:10. 1095/biolreprod60.3.702)

Witt O, Albig W \& Doenecke D 1996 Testis-specific expression of a novel human H3 histone gene. Experimental Cell Research 229 301-306. (doi:10.1006/excr.1996.0375)

Worrad DM, Ram PT \& Schultz RM 1994 Regulation of gene expression in the mouse oocyte and early preimplantation embryo: developmental changes in Sp1 and TATA box-binding protein, TBP. Development 120 2347-2357.

Wu F, Caron C, De Robertis C, Khochbin S \& Rousseaux S 2008 Testisspecific histone variants $\mathrm{H} 2 \mathrm{AL} 1 / 2$ rapidly disappear from paternal heterochromatin after fertilization. Journal of Reproduction and Development 54 413-417. (doi:10.1262/jrd.20067)

Wykes SM \& Krawetz SA 2003 The structural organization of sperm chromatin. Journal of Biological Chemistry 278 29471-29477. (doi:10. 1074/jbc.M304545200)

Yan W, Ma L, Burns KH \& Matzuk MM 2003 HILS1 is a spermatid-specific linker histone $\mathrm{H} 1$-like protein implicated in chromatin remodeling during mammalian spermiogenesis. PNAS 100 10546-10551. (doi:10. 1073/pnas.1837812100)
Yan W, Morozumi K, Zhang J, Ro S, Park C \& Yanagimachi R 2008 Birth of mice after intracytoplasmic injection of single purified sperm nuclei and detection of messenger RNAs and microRNAs in the sperm nuclei. Biology of Reproduction 78 896-902. (doi:10.1095/biolreprod.107. 067033)

Yao C, Wang Z, Zhou Y, Xu W, Li Q, Ma D, Wang L \& Qiao Z 2010 A study of $\mathrm{Y}$ chromosome gene mRNA in human ejaculated spermatozoa. Molecular Reproduction and Development 77 158-166. (doi:10.1002/ mrd.21116)

Zalenskaya IA \& Zalensky AO 2004 Non-random positioning of chromosomes in human sperm nuclei. Chromosome Research 12 163-173. (doi:10.1023/B:CHRO.0000013166.04629.97)

Zalenskaya IA, Bradbury EM \& Zalensky AO 2000 Chromatin structure of telomere domain in human sperm. Biochemical and Biophysical Research Communications 279 213-218. (doi:10.1006/bbrc.2000.3917)

Zalensky A \& Zalenskaya I 2007 Organization of chromosomes in spermatozoa: an additional layer of epigenetic information? Biochemical Society Transactions 35 609-611. (doi:10.1042/BST0350609)

Zalensky AO, Breneman JW, Zalenskaya IA, Brinkley BR \& Bradbury EM 1993 Organization of centromeres in the decondensed nuclei of mature human sperm. Chromosoma 102 509-518. (doi:10.1007/ BF00368344)

Zalensky AO, Siino JS, Gineitis AA, Zalenskaya IA, Tomilin NV, Yau P \& Bradbury EM 2002 Human testis/sperm-specific histone H2B (hTSH2B). Molecular cloning and characterization. Journal of Biological Chemistry 277 43474-43480. (doi:10.1074/jbc.M206065200)

Ziyyat A \& Lefevre A 2001 Differential gene expression in pre-implantation embryos from mouse oocytes injected with round spermatids or spermatozoa. Human Reproduction 16 1449-1456. (doi:10.1093/ humrep/16.7.1449)

Received 26 July 2010

First decision 12 August 2010

Revised manuscript received 12 September 2010

Accepted 27 September 2010 